\title{
Influence of a three-week wildlife education curriculum on knowledge and attitudes of South Carolina's Marlboro County High School ninth and tenth-grade biology students
}

\author{
Diane M. Krishon \\ West Virginia University
}

Follow this and additional works at: https://researchrepository.wvu.edu/etd

\section{Recommended Citation}

Krishon, Diane M., "Influence of a three-week wildlife education curriculum on knowledge and attitudes of South Carolina's Marlboro County High School ninth and tenth-grade biology students" (2004). Graduate Theses, Dissertations, and Problem Reports. 2008.

https://researchrepository.wvu.edu/etd/2008

This Thesis is protected by copyright and/or related rights. It has been brought to you by the The Research Repository @ WVU with permission from the rights-holder(s). You are free to use this Thesis in any way that is permitted by the copyright and related rights legislation that applies to your use. For other uses you must obtain permission from the rights-holder(s) directly, unless additional rights are indicated by a Creative Commons license in the record and/ or on the work itself. This Thesis has been accepted for inclusion in WVU Graduate Theses, Dissertations, and Problem Reports collection by an authorized administrator of The Research Repository @ WVU. For more information, please contact researchrepository@mail.wvu.edu. 


\title{
INFLUENCE OF A THREE-WEEK WILDLIFE EDUCATION CURRICULUM ON KNOWLEDGE AND ATTITUDES OF SOUTH CAROLINA'S MARLBORO COUNTY HIGH SCHOOL NINTH AND TENTH-GRADE BIOLOGY STUDENTS
}

\author{
Diane M. Krishon
}

Thesis submitted to the Davis College of Agriculture, Forestry and Consumer Sciences West Virginia University in partial fulfillment of the requirements

for the degree of

Master of Science in Agricultural Education

Stacy A. Gartin, Ph.D., Chair Harry N. Boone, Jr., Ph.D. Deborah A. Boone, Ph.D.

Division of Resource Management

$$
\begin{aligned}
& \text { Morgantown, West Virginia } \\
& 2004
\end{aligned}
$$

Keywords: Environment, Wildlife, Environmental Education, Conservation 


\begin{abstract}
Influence of a Three-week Wildlife Education Curriculum on Knowledge and Attitudes of South Carolina’s Marlboro County High School Ninth and Tenth-grade Biology Students
\end{abstract}

Diane M. Krishon

The purpose of this study was to assess the influence of a three-week wildlife education curriculum on knowledge and attitudes of ninth and tenth-grade biology students in South Carolina. A three-week wildlife curriculum was incorporated into three high school biology classes in the same semester. The students were pre-tested and post-tested for knowledge and attitudes. The results indicate that the three-week curriculum had a positive influence on knowledge but did not influence wildlife attitudes. However, a substantial correlation occurred between the post-test attitude and knowledge scores, indicating that as students' knowledge increased, their attitudes towards wildlife and environmental education became more positive. The study concluded that a three-week wildlife curriculum infused into an existing biology curriculum was not successful in significantly influencing environmental attitudes. Future research is needed to determine how environmental knowledge and attitudes are influenced by length of treatment, social economic status, race, culture, and gender. 


\section{ACKNOWLEDGEMENTS}

I would like to gratefully acknowledge Dr. Stacy Gartin who took me in without hesitation after years of not hearing from me. I also appreciate Dr. Harry Boone and Dr. Deborah Boone for serving on my thesis defense committee. Many thanks to Dr. Gary Wingenbach for his formatting and statistical contribution, advice, guidance, and faith that I would someday complete this project. I am grateful to Dr. Layle Lawrence for giving me peace of mind and helping me put together a plan when I was homeless.

To Dr. Laerm for instilling in me a love for science, research, and the Old Man Mountains. I affectionately dedicate this thesis to him.

I would like to thank my family, especially my parents, for their absolute confidence in me. I'm forever indebted to my Mom and Dad for their constant support emotional, moral and of course financial. To Cody for his faithful companionship.

Tom, thank you for your understanding, endless patience, encouragement, loyalty and devotion.

Many thanks to all my friends and colleagues, too numerous to name, who continuously inquired on the status of this thesis which kept me from shelving it. 


\section{TABLE OF CONTENTS}

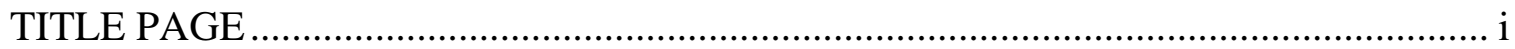

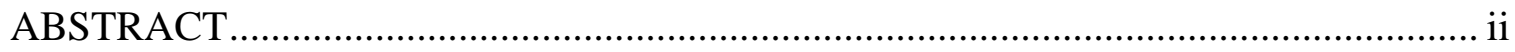

ACKNOWLEDGEMENTS ...................................................................................... ii

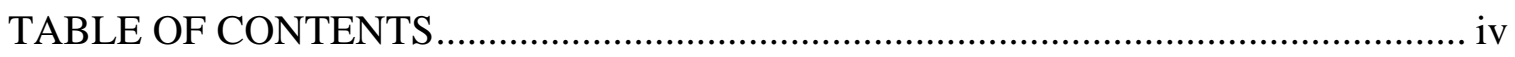

LIST OF TABLES ……………………......................................................... vi

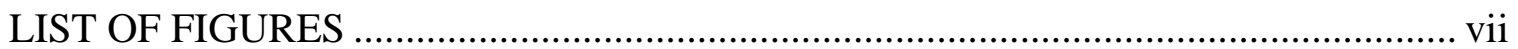

\section{CHAPTER}

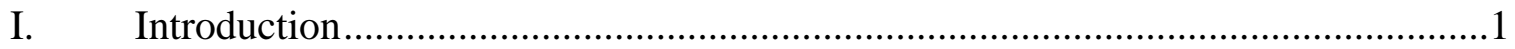

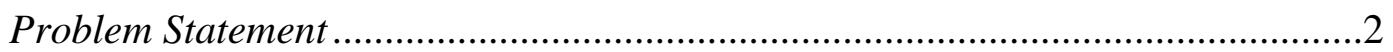

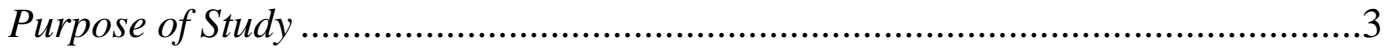

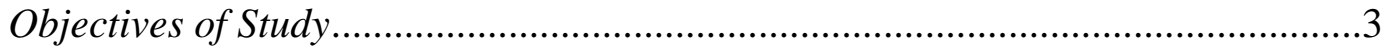

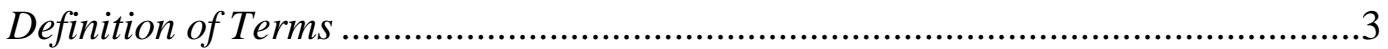

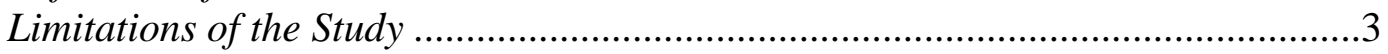

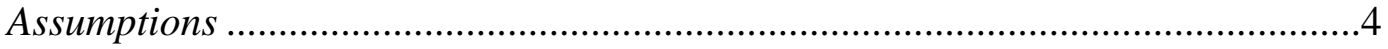

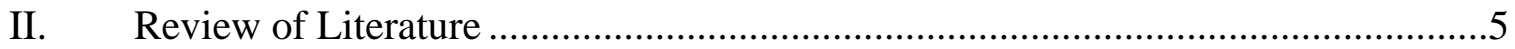

Assessment of Wildlife and/or Environmental Knowledge and Attitudes..................5

Environmental Education Curricula................................................................10

Wildlife Forever and Project WILD ...............................................................12

Summary of Literature Review........................................................................12

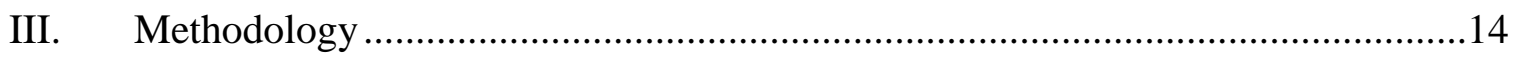

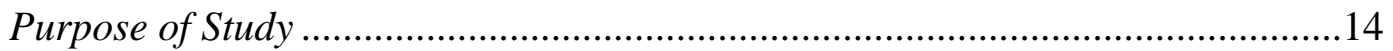

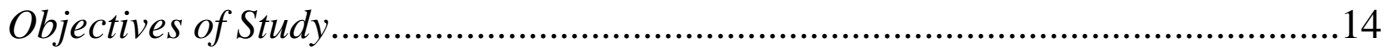

Research Design ……………………...........................................................14

Wildlife Forever and Project WILD ..............................................................15

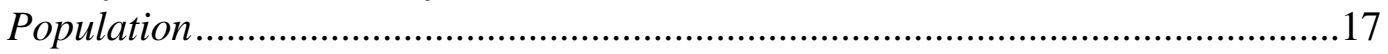

Instrumentation and Data Collection Procedures...............................................18

Instrument Validity ......................................................................................

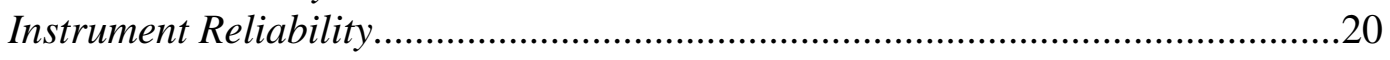

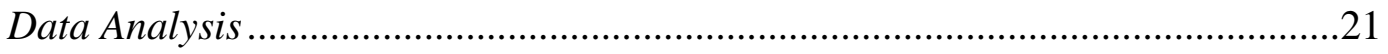

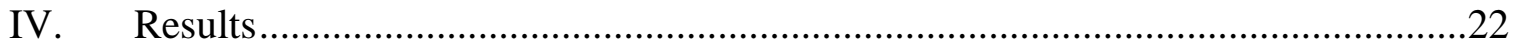




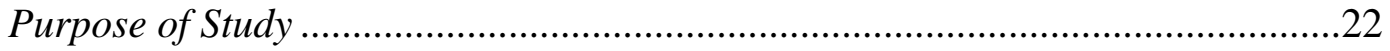

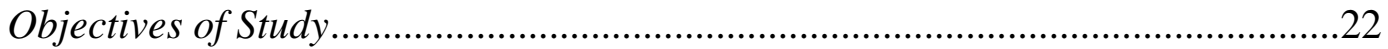

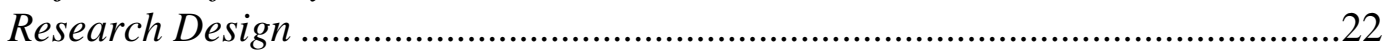

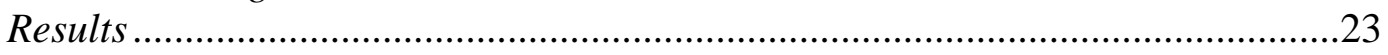

V. Summary, Conclusions and Recommendations.............................................35

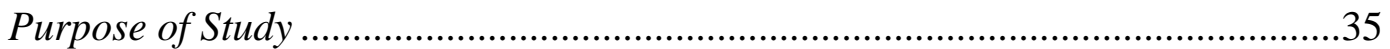

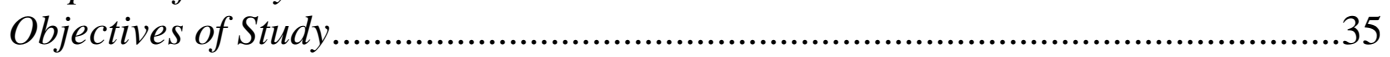

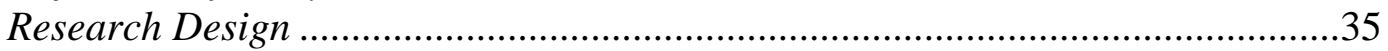

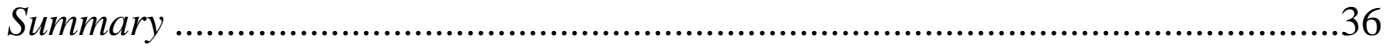

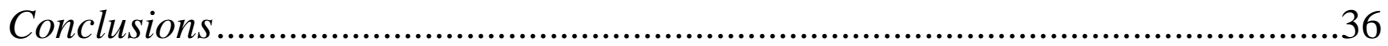

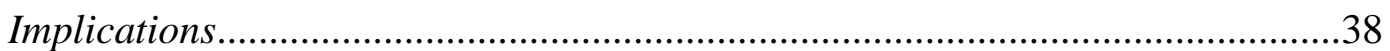

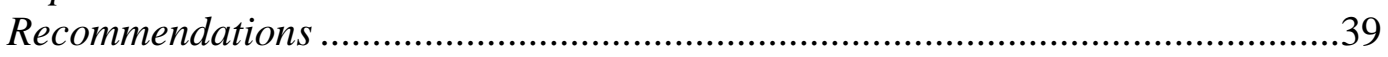

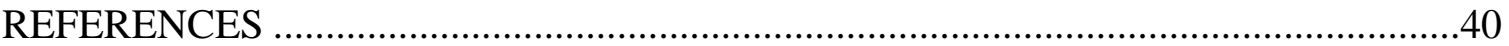

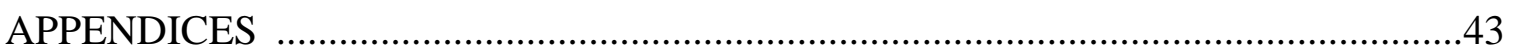

APPENDIX A: Wildlife Biology Unit Test............................................................44

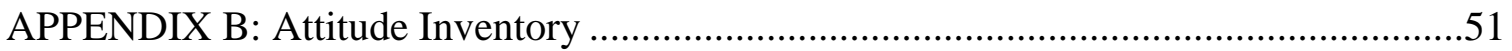

APPENDIX C: Knowledge Scores as Percentages ...................................................54

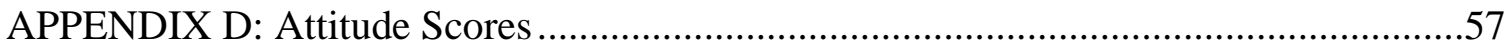

APPENDIX E: Pre-test Knowledge Scores Frequency Distribution..............................60

APPENDIX F: Post-test Knowledge Scores Frequency Distribution ............................62

APPENDIX G: Pre-test Attitude Scores Frequency Distribution..................................64

APPENDIX H: Post-test Attitude Scores Frequency Distribution .................................66

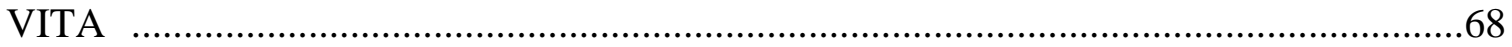




\section{LIST OF TABLES}

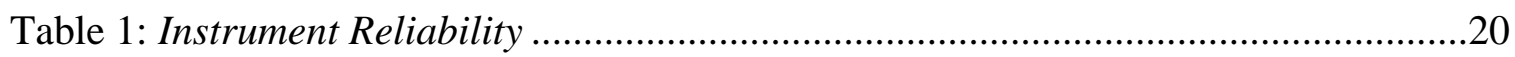

Table 2: Classification of Positive Statements According to Mean ...................................24

Table 3: Classification of Negative Statements According to Mean.................................24

Table 4: Pre-test Attitude Statements Sorted by Descending Mean .................................25

Table 5: Post-test Attitude Statements Sorted by Descending Mean ................................26

Table 6: Pre-test Knowledge Questions Listed by How Often They Were

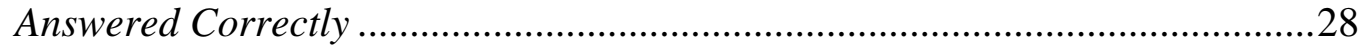

Table 7: Post-test Knowledge Questions Listed by How Often They Were Answered

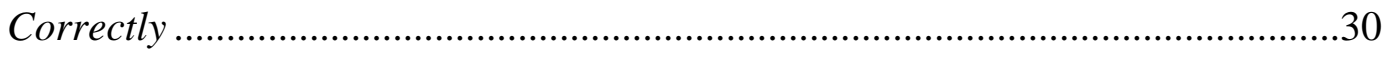

Table 8: Paired Samples Statistics and t Test.............................................................32

Table 9: Conventions Used to Describe Measures of Association ...................................33

Table 10: Pearson's Product Moment Correlations .........................................................33

Table A1: Knowledge Scores as Percentages ................................................................55

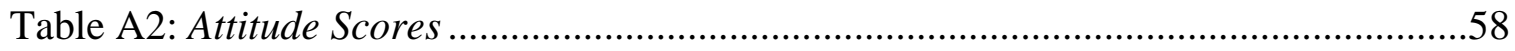




\section{LIST OF FIGURES}

Figure 1: Pre-test Knowledge Scores Frequency Distribution .......................................60

Figure 2: Post-test Knowledge Scores Frequency Distribution ....................................62

Figure 3: Pre-test Attitude Scores Frequency Distribution ..........................................64

Figure 4: Post-test Attitude Scores Frequency Distribution.........................................66 


\section{CHAPTER I}

Introduction

South Carolina is a state rich in natural resources and geographic diversity. Over two thirds of the entire state is forested. Of the state's 19.3 million acres, $63 \%$ or 12.6 million acres are forested (South Carolina Forestry Association, n.d.). South Carolina has a variety of geographical provinces which stretch from the Blue Ridge Mountains in the northwest corner to the Atlantic coast at the southeast corner. This diversity of landscapes allows South Carolina to cater to most forms of outdoor recreation including hunting, freshwater and saltwater fishing, and other wildlife-associated recreation.

South Carolina takes advantage of its natural resources in numerous ways. Forest Products is the State's second largest manufacturing industry with more than 1,000 firms employing over 30,000 people (South Carolina Forestry Association, n.d.).

The tourism industry benefits from South Carolina’s geographical diversity making it responsible for bringing in more new money than any other industry. Tourism is South Carolina's number one employer (Discover South Carolina, n.d.). In 1996, 40\% of the national adult population participated in some type of outdoor activity (hunting, fishing, wildlife watching) while spending \$100 billion (U. S. Department of the Interior, Fish and Wildlife Service and U. S. Department of Commerce, Bureau of the Census, 1996). That same year tourism contributed $\$ 6.5$ billion to South Carolina’s economy and generated 113,859 jobs in the state (South Carolina SC - Statistics Statistical Reports, n.d.).

In 1996, 2.8 million South Carolina residents and non-residents spent \$1.5 billion on wildlife-related activities such as hunting, fishing, and wildlife watching (U. S. 
Department of the Interior, Fish and Wildlife Service and U. S. Department of Commerce, Bureau of the Census, 1996). These numbers indicate that South Carolina's geographical diversity and abundant wildlife are valuable resources.

The value of these resources to South Carolina's economy will only appreciate over time. Increasing the emphasis of environmental education in South Carolina is imperative to the sound management of the state's natural resources, especially its wildlife resources. The only way to ensure dependable management of the future's natural resources is to educate the rising generation of stewards. "A broad public literacy of biological and ecological concepts is at the heart of defining, reclaiming and maintaining environmental quality...” (Rubin et al., as cited in Ramsey \& Rickson, 1976, p. 10). This study investigated the influence of a wildlife biology curriculum on wildlife knowledge and attitudes of ninth and tenth-grade biology students in South Carolina's Marlboro County High School.

\section{Problem Statement}

South Carolina's tourism industry is inextricably linked to and affected by wiseuse of the state's natural resources. As a major contributor to South Carolina's economy, the future of tourism is dependent upon a knowledgeable populace that values its wildlife resource base. Future generations will be ensured of a bountiful wildlife resource in South Carolina if prescriptive measures are implemented today. A paucity of evidence exists that wildlife and environmental education are being taught at the secondary school level. A need exists to determine the effectiveness of a three-week wildlife biology curriculum in influencing students' knowledge and attitudes on the subject. 


\section{Purpose of the Study}

The purpose of this study was to assess the influence of a three-week wildlife education curriculum on knowledge and attitudes of ninth and tenth-grade biology students in Marlboro County South Carolina.

\section{Objectives of the Study}

The specific objectives of this study were:

a) To determine whether there was a change in wildlife knowledge at the end of the three week curriculum.

b) To determine whether there was a change in wildlife attitudes at the end of the three week curriculum.

\section{Definition of Terms}

Project WILD - a conservation and environmental education program emphasizing wildlife (Project WILD).

Wildlife Forever - a national non-profit conservation organization comprised of private conservation organizations and state and federal agencies (McCarthy, 1998).

\section{Limitations of the Study}

The proposed study was limited by the short duration of the curriculum. Because the proposed curriculum was merged into an already existing high school biology curriculum, three weeks was the maximum duration allowed for the target material to be covered. An additional limitation was the study only took place in Marlboro County High School; therefore, any results and conclusions drawn from this study will be limited in their application because the sample is only representative of Marlboro County students. 


\section{Assumptions}

1. Ninth and tenth-grade biology students will posses a rudimentary understanding of the environment and wildlife prior to being taught the wildlife curriculum.

2. Ninth and tenth-grade biology students will have preconceived notions on the environment and wildlife prior to being taught the wildlife curriculum. 


\section{CHAPTER II}

\section{Review of Literature}

The purpose of this study was to assess the influence of a three-week wildlife education curriculum on knowledge and attitudes of ninth and tenth-grade biology students in Marlboro County South Carolina. To accomplish this purpose, the following review of literature was conducted. Specific emphasis was directed in assessment of wildlife and/or environmental knowledge and attitudes, environmental education curricula, and Wildlife Forever and Project WILD.

\section{Assessment of Wildlife and/or Environmental Knowledge and Attitudes}

Some investigators assume that a change in knowledge invariably leads to a change in attitude. While the relationship between environmental knowledge and attitude is unquestionable, the assumption that a positive change in knowledge leads to a positive change in attitude is generally accepted (Arcury, 1990 as cited in Bradley, Waliczec, \& Zajicek, 1999; Tufuor, 1982). Ramsey and Rickson (1976) address this assumption by stating there is a "circulatory between attitudes and knowledge in that one does not solely cause or even precede the other, but rather some knowledge may lead to initial formation of attitudes which in turn lead to the further gains in knowledge and so on” (p. 15).

Multiple studies attempting to link environmental knowledge to attitudes have yielded conflicting results. Some of these studies have found a positive increase in environmental knowledge and attitudes in junior high and high school students after being exposed to an environmental education program (Bradley et al., 1999; Dickey, 1994; Flint, 1991; Jordan, Hungerford, \& Tomera, 1986; Wilson and Tomera, 1980). Conversely, a study by Keen (1991), in which 27 fifth and sixth-grade classes (578 
students) took part in a five-day residential program, shows a positive change in knowledge after exposure to an environmental education course but no significant change in attitude. Similarly, based on results of a survey of more than 9,000 secondary school students in the Netherlands, Kuhlemeier, Van Den Bergh, and Lagerweij (1999) concluded that the relationship between environmental knowledge and environmental attitudes was considerably weak. It should be noted that the students lacked a solid environmental knowledge base but were still concerned about the present state of the environment.

Bradley et al. (1999) tested the effect of a ten-day environmental science curriculum on the knowledge and attitudes of high school students using a pre- and posttest design. Their results indicated there was a significant increase in both knowledge and attitudes following the environmental course. They also reported that for both preand post-test scores, the students with higher environmental knowledge had more positive environmental attitudes. Based on their results, Bradley et al. (1999) concluded that attitude could indeed be influenced by what is taught in the classroom.

A similar study conducted by Flint (1991) assessed the change in knowledge and attitudes of 88 high school students exposed to a ten-day outdoor education course. He divided the participants into two groups; a control group (34 students) and an experimental group (54 students). Flint's results show that there was a significant difference in post-test knowledge and attitude scores between the control and the experimental groups. He concluded that exposure to an environmental course significantly increases pro-environmental attitudes of participants. 
Dickey (1994) conducted a study evaluating the effects of a fourteen-hour wildlife conservation course on knowledge and attitudes of gifted upper elementary students. She divided the participants into a control group and an experimental group. Students in the control group were enrolled in a wildlife art class, while those students in the experimental group were enrolled in the wildlife education class. Dickey found no significant differences between the control group and the experimental group for the pre-test scores; however, there was a significant difference in post-test scores. The experimental group's scores were significantly higher than the control group's scores on both the knowledge and attitude post-tests. Dickey's results show that the wildlife course had a significant positive effect on the experimental group in both knowledge and attitudes of fourth, fifth, and sixth-graders.

A similar study by Hua (1996) evaluated the effects of selected Project WILD activities on wildlife and environmental knowledge and attitudes of fifth-graders. He examined both the long-term and short-term effects of implementing seven activities over four weeks. Hua found that short-term knowledge and attitudes increased after the activities were carried out, but these effects diminished over the long-term. He also discovered that children's behavior toward wildlife and the environment was more responsible after the activities. Hua recommended that these Project WILD activities be implemented on a continuous basis in order to have a long-term effect on children's knowledge and attitudes.

A study conducted with New York City sixth-graders revealed similar results to the previous studies. Students who participated in environmental education programs showed an increase in environmental knowledge and attitudes (Euler, 1988). 
A study by Tufuor (1982) focused on the change of attitude in students after an outdoor education program and attempted to pinpoint the aspects of the program which contributed to the change. The outdoor education program had a positive effect on both the attitude and behavior of students. Tufuor mentions that we assume a change in attitude will translate into a change in behavior, although there is no evidence to support this claim. Certain aspects of the program, which he suggests contributed to the change in attitude, were field study sessions, outdoor school environment, attitudes and behaviors of teachers, wildlife films, and teaching strategies.

Ford (1992) found that a wildlife program elicited a positive attitude change in students. This study focused specifically on whether an informal interpretive presentation would change knowledge and attitudes of fifth-graders toward snakes. Significant differences in both knowledge of snakes and student's attitudes toward snakes were apparent after the program. Interestingly, the students' attitudes toward bats and spiders, which are also considered to be species that elicit fear and negative responses, remained negative after the presentation. This suggests that the individual species need to be targeted in order to correct misconceptions and improve attitudes.

Jaus (1982) tested the effect of fifteen days (ten hours) of environmental education instruction on the environmental attitudes of fifth-graders. He stated that because attitudes are established by the time a student reaches high school; environmental education would be more effective in the elementary and middle school grades. The students tested were from a lower to middle socioeconomic background. Both the control group and the experimental group were administered an attitude inventory following instruction. Jaus found that the students who had received the environmental education 
instruction had significantly more positive attitudes towards the environment than those who did not receive the instruction. To ensure that the results were not caused by differences inherent of the two groups, the control group received the same fifteen day instruction following the initial attitude inventory. When post-tested, the control group also had a significantly higher positive attitude towards the environment following instruction.

Iozzi (1989) states that the relationship between environmental knowledge and attitudes is unclear. Previous studies have suggested that knowledge alone does not affect attitudes (Borden and Schettino, 1979; Newhouse, 1991). Whether or not previous studies succeed in proving a positive relationship between knowledge and attitudes, multiple factors that influence this relationship are addressed. Bradley et al., (1999), state that "outside influences such as life experiences, socioeconomic status and culture probably influence environmental attitudes” (p. 21). Horvat (as cited in Iozzi, 1989) found that increased previous knowledge, higher socioeconomic status, and a higher I.Q. were strongly related to environmental concern. The issue of gender yielded inconclusive results with a study by Hounshell and Liggett (1973), which found that females had a more positive attitude toward the environment than males did, and a conflicting study by Ayers (as cited in Iozzi, 1989) in which not relationship was found between attitudes and gender. Arcury \& Christianson (1993) investigated whether or not rural-urban differences influenced environmental views, concern, knowledge, and action. The sample population was Kentucky River Basin residents. They determined that the more urban residents were more knowledgeable and had stronger environmental views, but they did not differ from the more rural residents in environmental concern or actions. 
They did however find that variation in education and income accounted for the differences in environmental knowledge and views. The issue of race has also been addressed in earlier studies. Gigliotti (1990) mentions that "the environmental movement is primarily a white middle-class cause” (p. 10). Dolin (as cited in Gigliotti, 1990) summarizes previous research stating that "black's interest in, and knowledge about wildlife was much more limited than that of whites” (p. 10). An additional study by Sheppard (1995) found that African Americans were less likely to be concerned with resource conservation, pollution, and population growth than whites. All these factors need to be taken into consideration when creating environmental education programs. Curriculum needs to be tailored to meet the needs of the target population.

This study will help address the question of whether increased knowledge about the environment has a positive influence on the students' attitude on the environment.

\section{Environmental Education Curricula}

A topic of concern among environmental education researchers and investigators is the current status of environmental education in schools in the United States. An issue commonly addressed is whether it would be more effective for environmental education to be taught as a course in itself or whether it should be infused into existing curricula of varying subjects. Ramsey, Hungerford, \& Volk (1992) admit that revising existing curricula is a challenge, but that this strategy has untapped potential. He goes on to suggest that an alternative to restructuring existing curricula is to team-teach an environmental course. Ramsey et al. (1992) list the following subject areas as those in which environmental education concepts could be infused or as those whose teachers 
could be involved in team-teaching strategy: science, health, social studies, math, language arts, home economics, and agriculture.

Singletary (1992) also mentions that integrating environmental education into courses, which are departmentalized, would be difficult. He suggests that one solution, at the secondary school level, is to develop discrete environmental education courses and incorporate them into the science curriculum. Although this is a relatively simple solution, Singletary points out "secondary teachers have specialized training in one discipline, making it difficult for an individual teacher to incorporate the variety of perspectives necessary for comprehensive coverage of environmental issues” (p. 36). He does go on to admit that although team-teaching is a better alternative, it would be difficult to coordinate. "Integration leads to diffusion to the point where everything and anything becomes environmental education” (Singletary 1992, p. 40). Singletary concludes that the best solution is to develop clearly focused environmental education courses at the high school level and discrete lessons in the junior high school and middle school levels.

Hooper (1980) researched the adoption of wildlife education in California K-12 schools and found that teachers had an overall positive perception of environmental education, but factors existed that discouraged the implementation of a wildlife curriculum. Lack of time to develop a curriculum, lack of instructional materials, and lack of curriculum guides were the major factors.

A study of Wisconsin elementary and secondary school teachers reported that the top three reasons they did not incorporate environmental education in their curriculum 
were because the concepts were unrelated to their subject (28.8\%), lack of training or background (24.2\%), and lack of class time (14\%) (Lane, 1994).

\section{Wildlife Forever and Project WILD}

The proposed three-week curriculum for this study was based on three lessons from the Wildlife Forever curriculum guide and was supplemented with three Project WILD activities. Wildlife Forever is a non-profit conservation organization that funds conservation projects across the country. This organization developed the curriculum guide with assistance from the U.S. Fish and Wildlife Service, Division of Federal Aid. Their mission in developing the curriculum guide is to educate future generations on stewardship of the nation’s wildlife resources (McCarthy, 1998).

Project WILD is an environmental education program emphasizing wildlife, consisting of a collection of supplementary activities designed to be easily integrated into a variety of subjects. This program employs teaching techniques that encourage concept awareness and understanding, skill development, responsible environmental behavior, and challenges preconceived notions (Project WILD, n.d.).

Smith (1988) conducted a study on the use and effectiveness of Project WILD. A survey was sent to Oklahoma educators of K-12. Results showed that two-thirds of the respondents $(n=780)$ used Project WILD to supplement their lessons. Hua (1996) used selected Project WILD activities to test their short- and long-term effects on wildlife knowledge, attitudes and behavior of fifth-graders.

\section{Summary of Literature}

The literature shows that environmental education courses do indeed have a positive effect on knowledge and have the potential to positively influence attitude. This 
study helps address the question of whether increased knowledge about the environment improves the students' attitude about the environment. As suggested by Singletary (1992), teaching discrete environmental education units rather than integrating the material into existing curricula is a more effective strategy. 


\section{CHAPTER III}

\section{Methodology}

Purpose of the Study

The purpose of this study was to assess the influence of a three-week wildlife education curriculum on knowledge and attitudes of ninth and tenth-grade biology students in Marlboro County South Carolina.

Objectives of the Study

The objectives of this study were to:

a) Determine whether there was a change in wildlife knowledge at the end of the three weeks.

b) Determine whether there was a change in wildlife attitude at the end of the three weeks.

\section{Research Design}

A pre-experimental one-group pretest-posttest design was used in this study. This design involves using one group, pre-testing the group, administering the treatment, and post-testing the group. Ary, Jacobs, \& Razavieh (1996) list extraneous variables that could cause a difference between the pre- and post-test scores which could mistakenly be attributed to the treatment. Two obvious variables are history (events the students experience that may affect the dependent variable between the pre- and post-testing) and maturation (physical and mental changes students go through between the pre- and posttesting). The variance due to history and maturation increases as the time between preand post-testing increases (Ary et al., 1996). Because the time between the pre-test and the post-test was short (three weeks), the effects of these two extraneous variables should 
be minimal. The effect of the pretest on the population is another potential source of variance inherent to this design. Ary et al. (1996) state that subjects learn from taking a pre-test and react to it thus influencing the result of the post-test. Subjects may remember specific questions when presented with the material during the treatment and consequently answer the questions correctly when presented with the same questions in the post-test. "Test effect" was not addressed in this study. Another threat to internal validity in this design is mortality. This threat was not a factor in this study. Instrumentation can be a source of variance if the researcher develops different forms of the pre-test and the post-test. Because the same instrument was used in the pre- and postest, this threat was not a factor in this study. Regression is sometimes another source of internal validity with this design. Because population in this study was not chosen due to their performance on any other test, this threat was not a factor in this study (Dawson, 1997).

This pre-experimental design was used to collect the data that would determine whether or not a three-week wildlife curriculum influenced knowledge and attitudes of the sample population.

\section{Wildlife Forever and Project WILD}

The three lessons from the Wildlife Forever curriculum guide used in the study contain the following key concepts and objectives:

Lesson 1 - "Where in the World in Horicon Marsh?"

Key concepts: Ecosystems and Biomes

Objectives: 1) Students will define ecosystem and biome.

2) Students will identify the major biomes found in the United States. 
3) Students will describe characteristics associated with each biome.

4) Students will identify several wildlife species inhabitants of each biome.

Lesson 2 - "Home Sweet Home"

Key Concept: Wildlife Habitat

Objectives: 1) Students will define habitat and list the components.

2) Students will identify habitat requirements of several species.

3) Students will define home range and provide two examples.

4) Students will evaluate habitat.

5) Students will describe how land-use decisions impact wildlife habitat.

Lesson 3 - "Walk and Talk Like the Animals"

Key Concept: Animal Behavior

Objectives: 1) Students will describe several types of animal behavior.

2) Students will discuss reasons for several types of animal behavior.

3) Students will identify several species that display unique seasonal behavior such as hibernation.

4) Students will identify specific behavioral characteristics of several species.

In this study, three Project WILD activities were used to supplement the threeweek wildlife curriculum. The first activity, “First Impressions”, was used the first day of the lessons as an introductory exercise. Its objective was to recognize the value of animals' contributions to the ecosystem, particularly the more unpopular species. The second activity, "Deer Crossing”, was a case study in which the students design a 
management strategy to prevent a deer herd from being adversely affected by building a new highway. The last activity, “To Zone or Not to Zone”, was another case study in which the students were assigned roles to simulate a county commission meeting faced with multiple land-use decisions affecting the environment.

\section{Population}

The population for this study was ninth and tenth-grade students enrolled in the investigator’s applied biology classes during the 1999 spring semester at Marlboro County High School in Bennettsville, South Carolina. Applied biology is a lower level freshman and sophomore introductory biology class. The three-week wildlife curriculum was easily integrated into an introductory biology course and made relevant to a number of South Carolina standards already in the semester curriculum such as ecology, classification, population dynamics, and the animal and plant kingdoms. The flexibility of the investigator's semester biology curriculum allowed for the wildlife material to be incorporated. Marlboro County High School was on block scheduling, which broke school day up into four classes each lasting 90 minutes.

The population consisted of 46 students enrolled in the three classes taught by the investigator. The population contained 31 male students and 15 female students. The student residential background was a mix of rural farming and suburban residential. The students were represented mostly by lower and lower-middle socioeconomic classes. The ethnic background of the population was approximately 65\% African American (30 students) and 35\% Caucasian (16 students). 


\section{Instrumentation and Data Collection Procedures}

Students’ wildlife knowledge and attitudes were assessed using a pre- and posttest design. The study consisted of first administering a knowledge and attitude pre-test, implementing the three-week wildlife curriculum, and finally administering the knowledge and attitude assessment as a post-test. The same instrument was used for both tests.

The test instrument consisted of three sections. Section I and II contained the knowledge questions (see Appendix A) designed to determine to what extent the students met the lesson objectives. Section III contains the attitude questions (see Appendix B).

Knowledge Inventory. Section I contains thirty multiple-choice questions with four possible choices but only one correct answer. The knowledge questions were developed from the objectives of the three lessons used in the curriculum and also from the material contained in those three lessons. Section II contains fifteen true/false statements. The value of each question was one for a correct answer and zero for an incorrect answer. Students obtained a knowledge score based on the number of questions answered correctly in sections I and sections II with a minimum score of 0 and a maximum score of 45 .

Attitude Inventory. Section III contains the attitude inventory, which consisted of 26 questions, rated on a Likert-Type scale (Ary et al., 1996). The five possible responses to each statement were 1 (strongly disagree), 2 (disagree), 3 (undecided), 4 (agree), and 5 (strongly agree). This inventory was used to measure students' attitudes toward wildlife and the environment. It was developed from a combination of the lesson objectives and an existing attitude measurement scale used by Dickey (1994). In order to receive a 
single attitude score for students, negative statements were reverse coded so that the least favorable response (strongly agree) carried a weight of 1 , and the most favorable response (strongly disagree) carried a weight of 5. As a result, the higher the total score on the attitude inventory, the more favorable the student's attitude toward the environment, and the lower the total score, the less favorable the student's attitude toward the environment. A total attitude score between 130-79 indicated an overall positive attitude, and a total score below 78 indicates an overall negative attitude. A score of 78 is neutral.

Armstrong and Impara (1990) conducted a study on the effects of order of test administration on environmental attitudes. They found that in pre-test situations, when students know little or nothing on a particular subject, administering the cognitive test prior to the attitude test may lead to a more negative score on the attitude test due to frustration by the cognitive test.

In this investigation, the attitude pre-test was administered one day prior to the knowledge pre-test and the attitude post-test one day after the knowledge post-test in hopes of obtaining an attitude score independent of the knowledge test. Instrument Validity

Content validity of the instruments was established by submitting a copy of the instruments along with a copy of the content and objectives of the lessons in the curriculum to a panel of wildlife specialists in the Wildlife Department at West Virginia University. The wildlife specialists concurred that the knowledge questions of the research instrument effectively address the content and objectives in the lessons. They also concluded that the attitude section of the instrument is capable of differentiating 
between students with a positive attitude toward wildlife and the environment from those with a negative attitude toward wildlife and the environment.

Instrument Reliability

The Cronbach alpha, or coefficient alpha, was used to estimate score reliability of both the attitude and knowledge pre- and post-test instruments (see Table 1). This test may be used when an instrument is designed to measure range of values such as attitudes. Cronbach’s alpha is “the general formula for estimating internal consistency based on a determination of how all items on a test relate to all other items and to the total test” (Gay 1987, p. 587). A perfectly reliable instrument will have an alpha level of one. This reliability analysis revealed alpha coefficients of: knowledge pre-test, 0.56 ; knowledge post-test, 0.80; attitude pre-test, 0.56; attitude post-test, 0.79; total instrument pre-test, 0.63; total instrument post-test, 0.85 . The results supported the reliability of the instruments, confirming that they consistently measured students’ perceptions toward wildlife and the environment.

\section{Table 1}

Instrument Reliability

\begin{tabular}{lcc}
\hline Scales & Pre-test alpha & Post-test alpha \\
\hline Knowledge & .5632 & .8023 \\
Attitude & .5630 & .7917 \\
Total Instrument & .6257 & .8493 \\
\hline
\end{tabular}




\section{Data Analysis}

Knowledge and attitude changes were evaluated using the Statistical Package for the Social Sciences (SPSS). Paired sample $t$ tests were used to test for statistical significance between pre- and post-tests. Levels of significance were set a priori at $\mathrm{p}<.05$ for all statistical tests. To test the relationship between attitude and knowledge, Pearson’s product-moment correlation was used. (Ary et al., 1996) 


\section{CHAPTER IV}

Results

Purpose of the Study

The purpose of this study was to assess the influence of a three-week wildlife education curriculum on knowledge and attitudes of ninth and tenth-grade biology students in Marlboro County South Carolina.

Objectives of the study

The objectives of this study were to:

a) Determine whether there was a change in wildlife knowledge at the end of the three weeks.

b) Determine whether there was a change in wildlife attitude at the end of the three weeks.

\section{Research Design}

The data used to assess students’ wildlife knowledge and attitudes was collected using a pre-experimental one-group pretest-posttest design. The study consisted of first administering a knowledge and attitude pre-test, implementing the three-week wildlife curriculum, and finally administering the knowledge and attitude assessment as a posttest. The same instrument was used for both tests.

The test instrument consisted of three sections. Section I and II contained the knowledge questions (see Appendix A) designed to determine to what extent the students met the lesson objectives. Section III contains the attitude questions (see Appendix B). 
Results

Attitude statements were classified by the Likert-Type scale used in the study according to their means (see Tables 2 and 3). Table 2 was used to classify positive statements, and Table 3 was used to classify negative statements (which are indicated with an apteryx). Pre- and post-test attitude statements were sorted by highest mean (see Tables 4 and 5). The statement with the highest mean received the most positive response and the statement with the lowest mean received the least favorable response. The statement with the highest mean (4.48) in the pre-test was:”Every Person can help protect the environment”. According the Likert type scale used in the study, most of the students strongly agreed with this statement. The statement with the lowest mean (2.10) in the pre-test was: “Humans are the most important species on earth”. Because this was a negative question, the mean was classified according to Table 3 indicating that most students agreed with this statement. The statement with the highest mean (4.26) in the post-test was: "Recycling is important”. Using Table 2, most students agreed with this statement. The statement with the lowest mean (2.31) was the same statement that received the lowest mean on the pre-test: "Humans are the most important species on earth”. The total pre-test attitude score was 88.67 and the total post-test attitude score was 88.50 . 
Table 2

Classification of Positive Statements According to Mean

\begin{tabular}{l|l}
\hline Mean & Classification \\
\hline $5.0-4.51$ & Strongly Agree \\
$4.5-3.51$ & Agree \\
$3.5-2.51$ & Undecided \\
$2.5-1.51$ & Sisagree \\
$1.5-0$ & \\
\hline
\end{tabular}

Table 3

Classification of Negative Statements* According to Mean

\begin{tabular}{l|l}
\hline Mean & Classification \\
\hline $5.0-4.51$ & Strongly Disagree \\
$4.5-3.51$ & Disagree \\
$3.5-2.51$ & Undecided \\
$2.5-1.51$ & Strongly Agree \\
\hline $1.5-0$ & \\
\hline
\end{tabular}


Table 4

Pre-test Attitude Statements Sorted by Descending Mean $(N=42)$

\begin{tabular}{|c|c|c|}
\hline Statements & Mean & SD \\
\hline Every person can help protect the environment. & 4.48 & 0.80 \\
\hline Recycling is important. & 4.40 & 0.89 \\
\hline All living things have a right to exist. & 4.17 & 1.08 \\
\hline $\begin{array}{l}\text { People in the United States need to be concerned about the } \\
\text { protection of rainforests in other countries. }\end{array}$ & 3.98 & 0.87 \\
\hline * No harm is caused by plants becoming extinct. & 3.95 & 1.13 \\
\hline $\begin{array}{l}\text { * It is O.K. to build homes in places where endangered species } \\
\text { live. }\end{array}$ & 3.90 & 1.05 \\
\hline $\begin{array}{l}\text { Cures for many diseases may be found in plants located in } \\
\text { tropical rainforests. }\end{array}$ & 3.76 & 0.99 \\
\hline $\begin{array}{l}\text { * All mountain lions should be destroyed because they have } \\
\text { been known to attack people. }\end{array}$ & 3.76 & 1.12 \\
\hline * No harm is caused by animals becoming extinct. & 3.74 & 1.21 \\
\hline Hunting is a tool in managing wildlife populations. & 3.69 & 1.18 \\
\hline Science is an enjoyable subject. & 3.60 & 1.43 \\
\hline $\begin{array}{l}\text { * Ecosystems can recover from severe changes such as building } \\
\text { a highway through a forest. }\end{array}$ & 3.52 & 1.09 \\
\hline * There will be less pollution in the future than there is now. & 3.48 & 1.09 \\
\hline $\begin{array}{l}\text { Wetlands are one of the most important ecosystems in the } \\
\text { world }\end{array}$ & 3.45 & 0.92 \\
\hline Oil drilling in Alaska has harmful effects on the environment. & 3.43 & 1.19 \\
\hline $\begin{array}{l}\text { Loss of wildlife habitat is a good reason to stop expanding our } \\
\text { cities. }\end{array}$ & 3.40 & 1.21 \\
\hline $\begin{array}{l}\text { The government should spend more money on purchasing land } \\
\text { for wildlife refuges. }\end{array}$ & 3.40 & 1.06 \\
\hline The human population is too large. & 3.29 & 1.07 \\
\hline $\begin{array}{l}\text { * Animal species can find somewhere else to live when their } \\
\text { habitat is altered or destroyed. }\end{array}$ & 3.12 & 1.13 \\
\hline $\begin{array}{l}\text { Deforestation of tropical rainforests increases the effects of } \\
\text { global warming. }\end{array}$ & 3.05 & 1.13 \\
\hline $\begin{array}{l}\text { * People should eliminate living things that are harmful to } \\
\text { humans. }\end{array}$ & 3.00 & 1.21 \\
\hline $\begin{array}{l}\text { * Money now being spent to protect endangered plants should be } \\
\text { used instead to feed starving people. }\end{array}$ & 2.71 & 0.99 \\
\hline $\begin{array}{l}\text { * Obtaining oil from Alaska for fuel and heat is a good } \\
\text { justification for disturbing the environment. }\end{array}$ & 2.67 & 1.07 \\
\hline $\begin{array}{l}\text { * Money now being spent to protect endangered animals should } \\
\text { be used instead to feed starving people. }\end{array}$ & 2.60 & 1.04 \\
\hline In the future, families should have no more than two children. & 2.12 & 1.23 \\
\hline
\end{tabular}


Table 4 (continued)

Pre-test Attitude Statements Sorted by Descending Mean $(N=42)$

\begin{tabular}{lcr}
\hline Statements & Mean & SD \\
\hline$*$ Humans are the most important species on earth. & 2.10 & 1.16 \\
\hline & & \\
Attitude Total & 88.67 & 8.11 \\
\hline$*$ indicates negative statements & &
\end{tabular}

Table 5

Post-test Attitude Statements Sorted by Descending Mean $(N=42)$

\begin{tabular}{|c|c|c|}
\hline Statements & Mean & SD \\
\hline Recycling is important. & 4.26 & 1.04 \\
\hline Every person can help protect the environment. & 4.24 & .93 \\
\hline $\begin{array}{l}\text { * It is O.K. to build homes in places where endangered species } \\
\text { live. }\end{array}$ & 4.07 & 1.13 \\
\hline All living things have a right to exist. & 4.05 & .99 \\
\hline Oil drilling in Alaska has harmful effects on the environment. & 3.79 & 1.07 \\
\hline * No harm is caused by animals becoming extinct. & 3.79 & 1.07 \\
\hline Science is an enjoyable subject. & 3.76 & 1.25 \\
\hline $\begin{array}{l}\text { People in the United States need to be concerned about the } \\
\text { protection of rainforests in other countries. }\end{array}$ & 3.67 & 1.07 \\
\hline * No harm is caused by plants becoming extinct. & 3.64 & 1.12 \\
\hline Hunting is a tool in managing wildlife populations. & 3.60 & 1.01 \\
\hline $\begin{array}{l}\text { Cures for many diseases may be found in plants located in } \\
\text { tropical rainforests. }\end{array}$ & 3.57 & 1.19 \\
\hline $\begin{array}{l}\text { Wetlands are one of the most important ecosystems in the } \\
\text { world }\end{array}$ & 3.52 & .94 \\
\hline * There will be less pollution in the future than there is now. & 3.50 & 1.02 \\
\hline $\begin{array}{l}\text { * All mountain lions should be destroyed because they have } \\
\text { been known to attack people. }\end{array}$ & 3.40 & 1.29 \\
\hline $\begin{array}{l}\text { * People should eliminate living things that are harmful to } \\
\text { humans. }\end{array}$ & 3.38 & 1.03 \\
\hline $\begin{array}{l}\text { The government should spend more money on purchasing land } \\
\text { for wildlife refuges. }\end{array}$ & 3.33 & 1.12 \\
\hline $\begin{array}{l}\text { Loss of wildlife habitat is a good reason to stop expanding our } \\
\text { cities. }\end{array}$ & 3.29 & 1.20 \\
\hline $\begin{array}{l}\text { Deforestation of tropical rainforests increases the effects of } \\
\text { global warming. }\end{array}$ & 3.24 & 1.19 \\
\hline The human population is too large. & 3.21 & 1.22 \\
\hline
\end{tabular}


Table 5 (continued)

Post-test Attitude Statements Sorted by Descending Mean ( $N=42)$

\begin{tabular}{|c|c|c|}
\hline Statements & Mean & SD \\
\hline $\begin{array}{l}\text { * Money now being spent to protect endangered animals should } \\
\text { be used instead to feed starving people. }\end{array}$ & 3.05 & 1.08 \\
\hline $\begin{array}{l}\text { * Ecosystems can recover from severe changes such as building } \\
\text { a highway through a forest. }\end{array}$ & 3.00 & 1.21 \\
\hline $\begin{array}{l}\text { * Obtaining oil from Alaska for fuel and heat is a good } \\
\text { justificiction for disturbing the environment. }\end{array}$ & 2.98 & 1.12 \\
\hline $\begin{array}{l}\text { * Animal species can find somewhere else to live when their } \\
\text { habitat is altered or destroyed. }\end{array}$ & 2.85 & 1.31 \\
\hline $\begin{array}{l}\text { * Money now being spent to protect endangered plants should be } \\
\text { used instead to feed starving people. }\end{array}$ & 2.69 & 1.02 \\
\hline In the future, families should have no more than two children. & 2.44 & 1.30 \\
\hline
\end{tabular}

* indicates negative statements

Tables 6 and 7 sort the knowledge questions for both pre-test and post-test, respectively, by how many of the questions were answered correctly. The question which received the most correct answers (32) on the pre-test was a true/false question and read as follows: "Playing opossum refers to an animal playing dead for a period of time as a defense mechanism". The question which received the most incorrect answers (5) on the pre-test was a multiple choice question and read as follows: “The gradual change of plant and animal communities within an ecosystem over time is called". The question which received the most correct answers (39) on the post-test was a true/false question and read as follows: “An animal's habitat includes food, water, shelter, and space”. The question which received the most incorrect answers (7) on the pre-test was a multiple choice question and read as follows: "Migration (the seasonal movement of animals form one area to another and back) is triggered by”. Knowledge pre-test mean score was 18.44 and post-test mean score was 27.60 (see Table 8). 
Table 6

Pre-test Knowledge Questions: How Often They Were Answered Correctly (N=43)

\begin{tabular}{|c|c|c|}
\hline \multirow[t]{2}{*}{ Part I - Multiple Choice } & \multicolumn{2}{|c|}{ Answers } \\
\hline & Correct & Incorrect \\
\hline Beavers build homes called lodges out of which material? & 26 & 17 \\
\hline Animals communicate by means of: & 25 & 18 \\
\hline $\begin{array}{l}\text { Which is the single most influential factor that determines an } \\
\text { ecosystem? }\end{array}$ & 24 & 19 \\
\hline Which animal is not commonly found in the tundra? & 24 & 19 \\
\hline What is the definition of a biome? & 22 & 21 \\
\hline Which animal is not commonly found in temperate forests? & 22 & 21 \\
\hline Which of the following animals is not a carnivore? & 20 & 23 \\
\hline $\begin{array}{l}\text { Which of the following terms describes an animal that eats only } \\
\text { plant material? }\end{array}$ & 19 & 24 \\
\hline $\begin{array}{l}\text { Which of the following biomes is not found in the continental } \\
\text { United States? }\end{array}$ & 18 & 25 \\
\hline Permafrost is a layer of frozen soil that: & 18 & 25 \\
\hline Which feature is not found on animals living in extreme cold? & 18 & 25 \\
\hline Which biome contains the greatest diversity of plants and animals? & 18 & 25 \\
\hline $\begin{array}{l}\text { A prairie dog is most likely to inhabit which of the following } \\
\text { biomes: }\end{array}$ & 17 & 26 \\
\hline What is the definition of an ecosystem? & 16 & 27 \\
\hline The tundra biome is characterized by: & 16 & 27 \\
\hline Coniferous trees are those that: & 16 & 27 \\
\hline Which of the following statements correctly describes a riparian & & \\
\hline zone? & 16 & 27 \\
\hline The primary threat to wildlife is: & 16 & 27 \\
\hline Carrying capacity refers to: & 15 & 28 \\
\hline Which animal is not commonly found in grasslands? & 12 & 31 \\
\hline Which of the following birds would not be found in a wetland? & 12 & 31 \\
\hline Which substance makes up $60-80 \%$ of an animal's body? & 12 & 31 \\
\hline $\begin{array}{l}\text { Migration (the seasonal movement of animals from one area to } \\
\text { another and back) is triggered by: }\end{array}$ & 11 & 32 \\
\hline The term diurnal means: & 10 & 33 \\
\hline Which of the following animals is not a true hibernator? & 9 & 34 \\
\hline The term neo-tropical migrants refers to: & 9 & 34 \\
\hline What type of habitat does a muskrat live in? & 7 & 36 \\
\hline A population in any given area is made up of all the: & 7 & 36 \\
\hline Deciduous trees are those that: & 7 & 36 \\
\hline $\begin{array}{l}\text { The gradual change of plants and animal communities within an } \\
\text { ecosystem over time is called: }\end{array}$ & 5 & 38 \\
\hline
\end{tabular}


Table 6 (continued)

Pre-test Knowledge Questions: How Often They Were Answered Correctly (N=43)

\begin{tabular}{|c|c|c|}
\hline \multirow[t]{2}{*}{ Part II - True/False } & \multicolumn{2}{|c|}{ Answers } \\
\hline & Correct & Incorrect \\
\hline $\begin{array}{l}\text { "Playing opossum” refers to an animal playing dead for a period of } \\
\text { time as a defense mechanism. }\end{array}$ & 32 & 11 \\
\hline An animal's habitat includes food, water, cover and space. & 31 & 12 \\
\hline $\begin{array}{l}\text { There are more plants and animals per acre in a wetland than in } \\
\text { any other ecosystem in the United Sates. }\end{array}$ & 27 & 16 \\
\hline Most animals that live in deserts are only active at night. & 25 & 18 \\
\hline About one quarter of the earth's land is desert. & 24 & 19 \\
\hline Some birds build their nests on the ground. & 24 & 19 \\
\hline $\begin{array}{l}\text { The wild turkey is found in all states in the United States except in } \\
\text { Alaska. }\end{array}$ & 24 & 19 \\
\hline Most hoofed mammals are grazers and browsers. & 22 & 20 \\
\hline Swamps are the same as marshes. & 21 & 22 \\
\hline $\begin{array}{l}\text { Migratory birds navigate using the stars and the earth's magnetic } \\
\text { field. }\end{array}$ & 20 & 23 \\
\hline Deep bodies of water are richer in plant life. & 17 & 26 \\
\hline $\begin{array}{l}\text { Altricial chicks hatch covered in a fine layer of down with their } \\
\text { eyes open. }\end{array}$ & 17 & 26 \\
\hline $\begin{array}{l}\text { There are six major flyways or primary migratory routes for birds } \\
\text { in the United States. }\end{array}$ & 17 & 26 \\
\hline $\begin{array}{l}\text { The area of grassland in the Midwestern states has increased since } \\
1862 .\end{array}$ & 13 & 30 \\
\hline $\begin{array}{l}\text { A scavenger is an animal that hunts, kills and then eats other } \\
\text { animals. }\end{array}$ & 12 & 31 \\
\hline
\end{tabular}


Table 7

Post-test Knowledge Questions: How Often They Were Answered Correctly $(N=43)$

\begin{tabular}{|c|c|c|}
\hline \multirow{2}{*}{ Part I - Multiple Choice } & \multicolumn{2}{|c|}{ Answers } \\
\hline & Correct & Incorrect \\
\hline Which of the following animals is not a carnivore? & 36 & 7 \\
\hline Which feature is not found on animals living in extreme cold? & 34 & 9 \\
\hline Beavers build homes called lodges out of which material? & 34 & 9 \\
\hline Permafrost is a layer of frozen soil that: & 33 & 10 \\
\hline Coniferous trees are those that: & 33 & 10 \\
\hline Animals communicate by means of: & 33 & 10 \\
\hline $\begin{array}{l}\text { The gradual change of plants and animal communities within an } \\
\text { ecosystem over time is called? }\end{array}$ & 31 & 12 \\
\hline $\begin{array}{l}\text { Which of the following terms describes an animal that eats only } \\
\text { plant material? }\end{array}$ & 31 & 12 \\
\hline $\begin{array}{l}\text { Which is the single most influential factor that determines an } \\
\text { ecosystem? }\end{array}$ & 30 & 13 \\
\hline What is the definition of an ecosystem? & 30 & 13 \\
\hline Which animal is not commonly found in temperate forests? & 30 & 13 \\
\hline Which substance makes up $60-80 \%$ of an animal's body? & 30 & 13 \\
\hline What is the definition of a biome? & 29 & 14 \\
\hline $\begin{array}{l}\text { Which of the following biomes is not found in the continental } \\
\text { United States? }\end{array}$ & 28 & 15 \\
\hline Deciduous trees are those that: & 28 & 15 \\
\hline The term diurnal means: & 27 & 16 \\
\hline $\begin{array}{l}\text { A prairie dog is most likely to inhabit which of the following } \\
\text { biomes? }\end{array}$ & 26 & 17 \\
\hline Which biome contains the greatest diversity of plants and animals? & 26 & 17 \\
\hline The term neo-tropical migrants refers to: & 26 & 17 \\
\hline Carrying capacity refers to: & 25 & 18 \\
\hline Which animal is not commonly found in the tundra? & 24 & 19 \\
\hline The primary threat to wildlife is: & 24 & 19 \\
\hline The tundra biome is characterized by: & 22 & 21 \\
\hline Which of the following animals is not a true hibernator? & 21 & 22 \\
\hline $\begin{array}{l}\text { Which of the following statements correctly describes a riparian } \\
\text { zone? }\end{array}$ & 19 & 24 \\
\hline Which animal is not commonly found in grasslands? & 18 & 25 \\
\hline What type of habitat does a muskrat live in? & 17 & 26 \\
\hline A population in any given area is made up of all the: & 16 & 27 \\
\hline Which of the following birds would not be found in a wetland & 15 & 28 \\
\hline $\begin{array}{l}\text { Migration (the seasonal movement of animals from one area to } \\
\text { another and back) is triggered by: }\end{array}$ & 7 & 36 \\
\hline
\end{tabular}


Table 7 (continued)

Post-test Knowledge Questions: How Often They Were Answered Correctly ( $N=43)$

\begin{tabular}{lcc}
\hline Part II - True/False & \multicolumn{2}{c}{ Answers } \\
\cline { 2 - 3 } & Correct & Incorrect \\
\hline An animal's habitat includes food, water, cover and space. & 39 & 4 \\
$\begin{array}{l}\text { Most animals that live in deserts are only active at night. } \\
\text { "Playing opossum" refers to an animal playing dead for a period of }\end{array}$ & 38 & 5 \\
time as a defense mechanism. & 35 & 8 \\
$\begin{array}{l}\text { Migratory birds navigate using the stars and the earth's magnetic } \\
\text { field. }\end{array}$ & 30 & 13 \\
$\begin{array}{l}\text { Most hoofed mammals are grazers and browsers. } \\
\text { About one quarter of the earth's land is desert. }\end{array}$ & 28 & 15 \\
$\begin{array}{l}\text { Swamps are the same as marshes. } \\
\text { Some birds build their nests on the ground. }\end{array}$ & 26 & 15 \\
$\begin{array}{l}\text { Altricial chicks hatch covered in a fine layer of down with their } \\
\text { eyes open. }\end{array}$ & 26 & 17 \\
$\begin{array}{l}\text { There are more plants and animals per acre in a wetland than in } \\
\text { any other ecosystem in the United Sates. }\end{array}$ & 23 & 20 \\
$\begin{array}{l}\text { A scavenger is an animal that hunts, kills and then eats other } \\
\text { animals. }\end{array}$ & 22 & 21 \\
$\begin{array}{l}\text { There are six major flyways or primary migratory routes for birds } \\
\text { in the United States. }\end{array}$ & 22 & 21 \\
$\begin{array}{l}\text { Deep bodies of water are richer in plant life. } \\
\text { The area of grassland in the Midwestern states has increased since }\end{array}$ & 19 & 24 \\
$\begin{array}{l}\text { 1862. } \\
\text { The wild turkey is found in all states in the United States except in }\end{array}$ & 13 & 30 \\
Alaska. & & \\
\hline
\end{tabular}

Pre- and post-test scores for both knowledge and attitudes were analyzed using a paired $t$ test. . Levels of significance were set $a$ priori at $\mathrm{p}<.05$ for all statistical tests. A correlation test to find a relationship between knowledge and attitudes in the post-test scores was also conducted.

The results of the paired $t$ test show that there was not a significant difference between attitude pre- and post-test mean scores. There was however, a significant difference between knowledge pre- and post-test mean scores. 
The mean score of the attitude pre-test was 88.67 with a standard deviation of 8.11. The mean score of the attitude post-test was 88.50 with a standard deviation of 11.73. The mean score difference of 3.62 and produced a $t$ value of .117 which was not significant. The mean score of the knowledge pre-test was 18.44 with a standard deviation of 4.84 . The mean score of the post-test was 27.60 with a standard deviation of 6.71. The mean score difference of 9.16 produced a $t$ value of -8.526 which was significant at the .01 level (see Table 8).

While the there was no significant difference between attitude pre-test mean and attitude post-test mean, the frequency distributions (see Appendices $\mathrm{G}$ and $\mathrm{H}$ ) illustrate that some individual attitudes were influenced. The graph shows that some attitudes became more positive (increase of total attitude sore) and some attitudes became more negative (decrease of total attitude score). As a result of the post-test attitude scores increasing and decreasing, virtually canceling each other out, there was no significant difference between the pre- and post-test means.

Table 8

Paired Samples Statistics and t Test

\begin{tabular}{lccccc}
\hline Summated Scale Scores & N & Mean & SD & $t$ & Sig. \\
\hline Attitude Pre-test & 42 & 88.67 & 8.11 & .117 & .908 \\
Attitude Post-test & 42 & 88.50 & 11.73 & & \\
Knowledge Pre-test & 43 & 18.44 & 4.84 & -8.526 & $.000^{* *}$ \\
Knowledge Post-test & 43 & 27.60 & 6.71 & & \\
\hline
\end{tabular}

** Significant at the 0.01 level (2-tailed). 
Correlation analysis is a measure of linear association between two variables.

The correlation coefficient value ranges between -1.00 (a perfect negative relationship) and +1.00 (a perfect positive relationship). A value of 0 indicates no linear relationship (Hinkle, Wiersma, Jurs, 1994). While interpreting the correlation coefficient as a descriptive measure, Davis (1971) provided the following example (see Table 9).

Table 9

Conventions Used to Describe Measures of Association

\begin{tabular}{ll}
\hline Coefficient & Association Description \\
\hline .70 to 1.00 & Very Strong \\
.50 to .69 & Substantial \\
.30 to .49 & Moderate \\
.10 to .29 & Low \\
.01 to .09 & Negligible \\
\hline
\end{tabular}

A substantial significant correlation (.563) occurred between the post-test attitude and knowledge scores, indicating that as students' knowledge increased, their attitudes towards wildlife and environmental education became more positive (see Table 10).

Table 10

Pearson's Product Moment Correlations

\begin{tabular}{lllr}
\hline & & Attitude & Knowledge \\
\hline Summated Attitude Post-test & $\begin{array}{c}\text { Pearson Correlation } \\
\text { Sig. (2-tailed) }\end{array}$ & 1.000 & $.563^{* *}$ \\
Summated Knowledge Post-test & $\begin{array}{c}\text { Pearson Correlation } \\
\text { Sig. (2-tailed) }\end{array}$ & $.563^{* *}$ & 1.000 \\
\hline
\end{tabular}


Knowledge scores as percentages and attitude scores are listed in Appendices C and D, respectively. Appendix E shows a frequency distribution of the pre-test knowledge scores. Appendix F shows a frequency distribution of the post-test knowledge scores. Appendix G shows a frequency distribution of the pre-test attitude scores. Appendix H shows a frequency distribution of the post-test attitude scores. 


\section{CHAPTER V}

Summary, Conclusions, Implications and Recommendations

Purpose of the Study

The purpose of this study was to assess the influence of a three-week wildlife education curriculum on knowledge and attitudes of ninth and tenth-grade biology students in Marlboro County South Carolina.

Objectives of the study

The objectives of this study were to:

a) Determine whether there was a change in wildlife knowledge at the end of the three weeks.

c) Determine whether there was a change in wildlife attitude at the end of the three weeks.

\section{Research Design}

The data used to assess students’ wildlife knowledge and attitudes was collected using a pre-experimental one-group pretest-posttest design. The study consisted of first administering a knowledge and attitude pre-test, implementing the three-week wildlife curriculum, and finally administering the knowledge and attitude assessment as a posttest. The same instrument was used for both tests.

The test instrument consisted of three sections. Section I and II contained the knowledge questions (see Appendix A) designed to determine to what extent the students met the lesson objectives. Section III contains the attitude questions (see Appendix B). 


\section{Summary}

The results show that the three-week curriculum had a positive influence on knowledge; however, it did not influence wildlife attitudes. The lack of significant difference between the pre-test and post-test attitude scores indicates that integrating a three-week curriculum into a science class is not enough to impact environmental attitudes.

The ultimate objective of any environmental or wildlife education program is to positively influence behavior. "It seems that there is an assumption that attitudes affect behavior and that knowledge in turn affects attitudes” (Burrus-Bammel 1978, p. 41). According to Newhouse (1991), and Ramsey and Rickson (1976), one of the most important influences of behavior is attitude. Although this point is widely disputed, environmental researchers and educators continue to search for links between knowledge, attitudes and behavior. The reason this relationship is often the problem statement in environmental education programs, is that knowledge is the easiest and most convenient parameter to address when attempting to impact environmental attitudes.

\section{Conclusions}

The study of environmental knowledge, attitude, and behavior has profound implications for environmental conservation. Although some studies successfully link knowledge to attitudes, many more yield results that make this relationship inconclusive. The results of this study indicate that a three-week wildlife curriculum had a positive influence on knowledge but did not influence wildlife attitudes. There are several possible explanations for this result. 
The three-week curriculum was infused into an existing high school biology class which was mandatory. Armstrong and Impara (1990) reported no change in environmental attitudes after volunteer teachers incorporated the program NatureScope into their fifth and seventh-grade science classes. They concluded that one possible reason for the lack of change in attitude was that the material was presented in a mandatory setting. The fact that the students in this study had no choice in participating in the three-week wildlife curriculum may have created a negative bias from the beginning.

Another factor that could have had a negative effect on the students was that the material was taught in the classroom. There were no outdoor experiences or guest speakers to reinforce the concepts that were being taught. Keen (1991) found that the time children spent outdoors was directly related to a positive attitude toward learning about nature. Iozzi (1989) states that "outdoor education is an effective way of improving environmental attitudes and values” (p. 7).

An additional limitation was that students were only exposed to the material for three weeks. It is my opinion that the majority of the students who participated in this study had very limited previous outdoor life-experiences, which play an influential role in forming values systems. Attitude and behavior are products of values and value systems. "Wilderness values tend to be developed early in life and reinforced throughout life..." (Hendee, Catton, Marlow, \& Brockman, as cited in Newhouse, 1991, p. 28). It is imperative that students have access to early-life environmental experiences so that environmental appreciation and awareness become part of their value system. 


\section{Implications}

The most obvious implication of this study is that the students were not exposed to the material long enough to have a positive impact on environmental attitudes.

Bryant and Hungerford (1977) point out that people’s attitude towards the environment start to develop at an early age. Iozzi (1998) presented 8 major ideas concerning the affective domain and environmental education. One of these ideas states that environmental attitudes and values should begin to develop before kindergarten and be regularly reinforced throughout elementary, middle and high school. This opinion is supported by Singeltary (1992) who suggests integrating environmental education throughout the curriculum beginning with specific environmental units and activities in the elementary and middle school and clearly focused environmental material and courses at the high school level.

An issue that presents itself when specific environmental units and courses are suggested is teacher specialization and training. This needs to be a point of focus because when teachers are not properly trained and feel uncomfortable teaching the subject, they could inadvertently create negative attitudes and feeling towards the topic. King and McGinnies (as cited in Burrus-Bammel, 1978) state that one of the most stable and replicable relationships in social psychology is that of communicator credibility with attitude change. Hooper (1980) reports that $85 \%$ of the teachers he surveyed would be willing to participate in environmental in-service training. Increasing teacher training would ensure credibility and eliminate the factor of creating a negative bias due to lack of knowledge. 


\section{Recommendations}

Of the factors that have been previously addressed in trying to link knowledge, attitudes, and behavior, several can not be controlled. These include gender, socioeconomic class, urban or rural residence, race, and culture. We must therefore concentrate our environmental educational efforts on those factors which can be influenced such as previous knowledge, long-term exposure, early-life experiences, hands-on activities, and speaker credibility.

Infusing environmental education throughout a student's career, beginning in kindergarten and ending in high school, would address the issues of early-life experiences, long-term exposure, and previous knowledge. Teacher training ensures speaker credibility and provides a forum for exchange of ideas for hands-on activities.

Future research is needed to determine how environmental knowledge and attitudes are influenced by length of treatment, social economic status, gender, culture, and race.

The goal of environmental education is not to overwhelm students with environmental facts and issues but to instill an environmentally literate and responsible foundation. Given this foundation, the future of the environment and its resources will be in capable hands. 


\section{REFERENCES}

Arcury, T. A., \& Christianson, E. H. (1993). Rural-urban differences in environmental knowledge and actions. Journal of Environmental Education, 25(1), 19-25.

Armstrong, J. B., \& Impara, J. C. (1990). The effects of order of test administration on environmental attitudes. Journal of Environmental Education, 21(3), 37-39.

Ary, D., Jacobs, L., \& Razavieh, A. (1996). Introduction to research in education. (5 $^{\text {th }}$ ed.). Ft. Worth: Holt, Rinehart, and Winston, Inc.

Borden, R. J., \& Schettino, A. (1979). Determinants of environmentally responsible behavior: Facts or feelings? Journal of Environmental Education, 10(4), 35-37.

Bradley, J. C., Waliczec, T. M., \& Zajicek J. M. (1999). Relationship between environmental knowledge and environmental attitude of high school students. Journal of Environmental Education, 30(3), 17-21.

Bryant, C. K., \& Hungerford, H. R. (1977). An analysis of strategies for teaching environmental concepts and values clarification in kindergarten. Journal of Environmental Education. 9(1), 44-49.

Burrus-Bammel, L. (1978). Information's effect on attitude: A longitudinal study. Journal of Environmental Education, 9(4), 41-51.

Davis, J. A. (1971). Elementary survey analysis. Englewood, NJ: Prentice-Hall.

Dawson, T. E. (1997). A primer on experimental and quasi-experimental design. Texas A \& M University. Retrieved July, 2004 from http://www.tele.sunyit.edu/expdes. HTM

Dickey, E. J. (1994). The effects of a wildlife conservation course on the knowledge and attitudes of gifted upper elementary students. Unpublished master's thesis, California State University, Fullerton.

Discover South Carolina Home page. (n.d.). Retrieved June 15, 2004, from http://www.discoversouthcarolina.com/agency/researchreports.asp/

Euler, A. (1988). A comparative study of the effectiveness of a formal vs. nonformal environmental education program for male and female sixth-grade students' environmental knowledge and attitudes. Dissertation Abstracts. AAG8819790.

Flint, K. J. (1991). Outdoor environmental education: its effects on high school students' knowledge and attitudes. Dissertation Abstracts. AAG1343986. 
Ford, C. S. (1992). The influence of experimental nonformal learning strategies on fifth-grade students' knowledge and attitudes toward snakes (snakes, wildlife education). Dissertation Abstracts. AAG9304435.

Gay, L. (1987). Educational Research: Competencies for analysis and application $\left(4^{\text {th }}\right.$ ed.). New York: Macmillan Publishing Company.

Gigliotti, L. M. (1990). Environmental education: What went wrong? What can be done? Journal of Environmental Education, 22(1) 9-12.

Hinkle, D., Wiersma, W., \& Jurs, S. (1994). Applied statistics for the behavioral sciences. Boston: Houghton Mifflin Company.

Hooper, J. K. (1980). Diffusion of environmental education: Adoption of wildlife ecology education in California K-12 schools. Dissertation Abstracts. AAG8112001.

Hounshell P., \& Liggett, L. (1973). Assessing the effectiveness of environmental education. Journal of Environmental Education, 5(2), 28-30.

Hua, H. (1996). Effects of the implementation of selected activities from Project WILD on fifth-grade children's knowledge about, and behaviors toward, wildlife and the environment. Dissertation Abstracts. AAG9705863.

Iozzi, L. A. (1989). What research says to the educator., Part one: Environmental education on the affective domain. Journal of Environmental Education, 20(3), 3-9.

Jaus, H. H. (1982). The effect of environmental education instruction on children's attitudes toward the environment. Science Education. 66(5), 689-692.

Jordan, J. R., Hungerford, H. R., \& Tomera, A. N. (1986). Effects of two residential environmental workshops on high school students. Journal of Environmental Education, 18(1), 15-21.

Keen, Meg. (1991). The effect of the Sunship Earth Program on knowledge and attitude development. The Journal of Environmental Education, 22(3), 28-32.

Kuhlemeier, H., Van Den Bergh, H., \& Lagerweij, N. (1999). Environmental knowledge, attitudes, and behavior in Dutch secondary education. The Journal of Environmental Education, 30(2) 4-14.

Lane, J., Wilke, R., Champeau, R., \& Sivek, D. (1994). Environmental education in Wisconsin: A teacher survey. Journal of Environmental Education, 25(4), 9-17. 
McCarthy, A. E. (1998). Wildlife Forever. U.S, Fish and Wildlife Service, Division of Federal Aid.

Newhouse, N. (1991). Implications of attitude and behavior research for environmental conservation. Journal of Environmental Education, 22(1), 26-32.

Project WILD. (1992). Bethesda, MD: Western Regional Environmental Education Council, Inc.

Ramsey, C. E., \& Rickson, R. E. (1976). Environmental knowledge and attitudes. The Journal of Environmental Education, 8(1), 10-18.

Ramsey, J. M., Hungerford H. R., \& Volk T., L. (1992). Environmental education in the K-12 curriculum: Finding a niche. Journal of Environmental Education, 23 (2), 35-45.

Sheppard, J. A. C., (1995). The Black-White environmental concern gap: An examination of environmental paradigms. Journal of Environmental Education, 26(2), 24-35.

Singletary, T. J. (1992). Case studies of selected high school environmental education classes. Journal of Environmental Education, 23 (4), 35-40.

Smith, C. L. (1988). An assessment of the use and effectiveness of Project WILD (Wildlife in Learning Design) by teacher and youth leaders in Oklahoma. Dissertation Abstracts. AAG8900437

South Carolina Forestry Association. (n.d.). Retrieved October 1998, from http://www.scforestry.org/wood/index.htm

South Carolina SC - Statistics Statistical Reports. (n.d.). Retrieved October 1998, from http://www.sciway.net/statistics/

Tufuor, J., K. (1982). Changes in students' attitudes towards conservation resulting from outdoor education: A case study. Dissertation Abstracts. AAG0554361

U. S. Department of the Interior, Fish and Wildlife Service and U. S. Department of Commerce, Bureau of the Census. (1996). 1996 National Survey of Fishing, Hunting, and Wildlife-Associated Recreation.

Wilson, R. J., \& Tomera, A. N. (1980). Enriching traditional biology with an environmental perspective. Journal of Environmental Education, 12(1), 8-12. 


\section{APPENDICES}


APPENDIX A

Wildlife Biology Knowledge Assessment 


\section{WILDLIFE BIOLOGY UNIT TEST}

PART I - Multiple Choice

1. What type of habitat does a muskrat live in?
a. desert
b. marsh
c. coniferous forest
d. grassland

2. What is the definition of a biome?
a. climate of a country
b. group of ecosystems with similar climate and communities
c. average rainfall of an area
d. all the plant species that inhabit an area

3. Which is the single most influential factor that determines an ecosystem?
a. climate
b. latitude
c. rainfall
d. temperature

4. What is the definition of an ecosystem?
a. all the living organisms in a certain area
b. all of the non-living organisms in a certain area
c. the interaction of plants and animals with their environment
d. the interaction of two species in a certain area

5. Which of the following biomes is not found in the continental United States?
a. coniferous forest
b. grassland
c. desert
d. tundra

6. The gradual change of plants and animal communities within an ecosystem over time is called?
a. natural selection
b. succession
c. evolution
d. genetic drift

7. A population in any given area is made up of all the:
a. consumers
b. all living and non-living organisms
c. all living organisms
d. individuals of one species 


\section{WILDLIFE BIOLOGY UNIT TEST (continued)}

8. A prairie dog is most likely to inhabit which of the following biomes?
a. grassland
b. desert
c. saltwater
d. temperate deciduous

9. Which animal is not commonly found in temperate forests?
a. gray squirrel
b. red fox
c. white-tailed deer
d. bison

10. Permafrost is a layer of frozen soil that:
a. melts once a year
b. never melts
c. melt many times throughout the year
d. is found in coniferous forests

11. Which animal is not commonly found in the tundra?
a. raccoon
b. rocky mountain goat
c. snowy owl
d. polar bear

12. Deciduous trees are those that:
a. remain green year around
b. are commonly found in deserts
c. lose their leaves each year
d. keep their leaves year around

13. The tundra biome is characterized by:
a. the types of animals and plants that inhabit the area
b. a frozen layer of oil called permafrost
c. its global location
d. its elevation

14. Which animal is not commonly found in grasslands?
a. pronghorn antelope
b. badger
c. elk
d. black bear 


\section{WILDLIFE BIOLOGY UNIT TEST (continued)}

15. Coniferous trees are those that:

a. have cones

b. are commonly found in tropical rainforests

c. loose their leaves each year

d. do not grow above ten feet

16. Which feature is not found on animals living in extreme cold?
a. short ears
b. short legs
c. layer of fat
d. long legs

17. Which biome contains the greatest diversity of plants and animals?
a. tundra
b. fresh water
c. tropical rainforest
d. desert

18. Which of the following statements correctly describes a riparian zone?
a. area where a forest meets an open field
b. area next to streams, rivers, lakes and wetlands
c. area where fresh water and salt water meet
d. any area where hunting is not allowed

19. Which of the following birds would not be found in a wetland
a. osprey
b. great blue heron
c. Canada goose
d. ruffed grouse

20. Which of the following terms describes an animal that eats only plant material?
a. omnivore
b. carnivore
c. herbivore
d. insectivore

21. Which of the following animals is not a carnivore?
a. white-tailed deer
b. bald eagle
c. wolf
d. cougar 


\section{WILDLIFE BIOLOGY UNIT TEST (continued)}

22. Which substance makes up $60-80 \%$ of an animal's body?
a. skin
b. muscle
c. carbon
d. water

23. Beavers build homes called lodges out of which material?
a. sticks and mud
b. sand
c. pine needles
d. grass

24. Carrying capacity refers to:

a. the number of young a mother can carry on her back

b. how much food a chipmunk can store in the fall

c. maximum number of individuals an area can support

d. the local environment in which an animal lives

25. The primary threat to wildlife is:
a. pollution
b. loss of habitat
c. predation
d. over population

26. Animals communicate by means of:
a. posture
b. scent marking
c. sounds
d. all of the above

27. The term diurnal means:
a. animals which are active during the day
b. animals which are active at dusk and dawn
c. animals which sleep during the day
d. the time of year when days are longer than nights

28. Migration (the seasonal movement of animals from one area to another and back) is triggered by:
a. seasonal fires
b. seasonal floods
c. length of daylight
d. temperature 


\section{WILDLIFE BIOLOGY UNIT TEST (continued)}

29. Which of the following animals is not a true hibernator?

a. ground squirrel

b. black bear

c. chipmunk

d. ground hog

30. The term neo-tropical migrant refers to:

a. birds that over-winter in Central and South America

b. birds which live their whole lives in the tropics

c. the tropical areas of the world

d. birds which spend their whole lives in North America

\section{PART II - True / False}

1. The area of grassland in the Midwestern states has increased since 1862.

2. About one quarter of the earth's land is desert.

3. Most animals that live in deserts are only active at night.

4. There are more plants and animals per acre in a wetland than in any other ecosystem in the United Sates.

5. Swamps are the same as marshes.

6. Deep bodies of water are richer in plant life.

7. A scavenger is an animal that hunts, kills and then eats other animals.

8. An animal's habitat includes food, water, cover and space.

9. Some birds build their nests on the ground.

10. The wild turkey is found in all states in the United States except in Alaska.

11. Altricial chicks hatch covered in a fine layer of down with their eyes open.

12. Most hoofed mammals are grazers and browsers.

13. There are six major flyways or primary migratory routes for birds in the United States.

14. Migratory birds navigate using the stars and the earth’s magnetic field. 


\section{WILDLIFE BIOLOGY UNIT TEST (continued)}

15. "Playing opossum” refers to an animal playing dead for a period of time as a defense mechanism. 
APPENDIX B

Wildlife Biology Attitude Inventory 


\section{WILDLIFE BIOLOGY ATTITUDE INVENTORY}

\section{$\underline{\text { PART III }}$}

Directions: Please place an $\mathrm{X}$ in the category which most closely matches the way you feel about each statement.

Key: $\mathrm{SD}=$ Strongly disagree; $\mathrm{D}=$ Disagree; $\mathrm{U}=$ Undecided: $\mathrm{A}=$ Agree; $\mathrm{SA}=$ Strongly Agree.

Statements

SD D U A SA

1. Wetlands are one of the most important ecosystems in the world

2. Oil drilling in Alaska has harmful effects on the environment.

3. Obtaining oil from Alaska for fuel and heat is a good justification for disturbing the environment.

4. Ecosystems can recover from severe changes such as building a highway through a forest.

5. Loss of wildlife habitat is a good reason to stop expanding our cities.

6. Humans are the most important species on earth.

7. Animal species can find somewhere else to live when their habitat is altered or destroyed.

8. Deforestation of tropical rainforests increases the effects of global warming.

9. People in the United States need to be concerned about the protection of rainforests in other countries.

10. Cures for many diseases may be found in plants located in tropical rainforests.

11. All mountain lions should be destroyed because they have been known to attack people.

12. In the future, families should have no more than two children.

13. Every person can help protect the environment.

14. Money now being spent to protect endangered plants should be used instead to feed starving people.

15. Money now being spent to protect endangered animals should be used instead to feed starving people.

16. It is O.K. to build homes in places where endangered species live.

17. The government should spend more money on purchasing land for wildlife refuges.

18. There will be less pollution in the future than there is now.

19. No harm is caused by plants becoming extinct.

20. No harm is caused by animals becoming extinct.

21. Recycling is important.

22. People should eliminate living things that are harmful to humans.

23. All living things have a right to exist. 
WILDLIFE BIOLOGY ATTITUDE INVENTORY (continued)

\section{Statements}

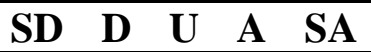

24. The human population is too large.

25. Hunting is a tool in managing wildlife populations.

26. Science is an enjoyable subject. 
APPENDIX C

Table A1

Knowledge Scores as Percentages 
Table A1

Knowledge Scores as Percentages $\quad N=43$

\begin{tabular}{|c|c|c|}
\hline ID & Pre-test & Post-test \\
\hline 1 & 20 & 47 \\
\hline 2 & 23 & 69 \\
\hline 3 & 24 & 80 \\
\hline 4 & 24 & 56 \\
\hline 5 & 27 & 69 \\
\hline 6 & 29 & 40 \\
\hline 7 & 31 & 42 \\
\hline 8 & 31 & 56 \\
\hline 9 & 33 & 69 \\
\hline 10 & 33 & 76 \\
\hline 11 & 36 & 67 \\
\hline 12 & 36 & 64 \\
\hline 13 & 36 & 53 \\
\hline 14 & 38 & 36 \\
\hline 15 & 38 & 40 \\
\hline 16 & 38 & 51 \\
\hline 17 & 40 & 73 \\
\hline 18 & 40 & 58 \\
\hline 19 & 40 & 69 \\
\hline 20 & 40 & 80 \\
\hline 21 & 40 & 49 \\
\hline 22 & 42 & 67 \\
\hline 23 & 42 & 62 \\
\hline 24 & 42 & 42 \\
\hline 25 & 42 & 44 \\
\hline 26 & 44 & 62 \\
\hline 27 & 44 & 71 \\
\hline 28 & 44 & 67 \\
\hline 29 & 44 & 36 \\
\hline 30 & 44 & 36 \\
\hline 31 & 44 & 44 \\
\hline 32 & 44 & 60 \\
\hline 33 & 47 & 76 \\
\hline 34 & 47 & 60 \\
\hline 35 & 49 & 53 \\
\hline 36 & 53 & 69 \\
\hline 37 & 56 & 73 \\
\hline 38 & 56 & 89 \\
\hline 39 & 56 & 84 \\
\hline 40 & 60 & 64 \\
\hline 41 & 60 & 62 \\
\hline
\end{tabular}


Table A1 (continued)

Knowledge Scores as Percentages $\quad N=43$

\begin{tabular}{ccc}
\hline ID & Pre-test & Post-test \\
\hline 42 & 60 & 84 \\
43 & 64 & 89 \\
\hline
\end{tabular}




\section{APPENDIX D}

Table A2

Attitude Scores 
Table A2

Attitude Scores $\quad N=42$

\begin{tabular}{|c|c|c|}
\hline ID* & Pre-test & Post-test \\
\hline 1 & 73 & 63 \\
\hline 2 & 73 & 73 \\
\hline 3 & 74 & 78 \\
\hline 4 & 76 & 78 \\
\hline 5 & 77 & 77 \\
\hline 6 & 77 & 81 \\
\hline 7 & 77 & 68 \\
\hline 8 & 77 & 77 \\
\hline 9 & 78 & 88 \\
\hline 10 & 78 & 78 \\
\hline 11 & 79 & 72 \\
\hline 12 & 79 & 74 \\
\hline 13 & 79 & 81 \\
\hline 14 & 80 & 91 \\
\hline 15 & 80 & 77 \\
\hline 16 & 80 & 106 \\
\hline 17 & 80 & 82 \\
\hline 18 & 81 & 74 \\
\hline 19 & 82 & 78 \\
\hline 20 & 82 & 94 \\
\hline 21 & 83 & 85 \\
\hline 22 & 83 & 88 \\
\hline 23 & 84 & 96 \\
\hline 24 & 84 & 87 \\
\hline 25 & 85 & 87 \\
\hline 26 & 85 & 85 \\
\hline 27 & 86 & 80 \\
\hline 28 & 86 & 84 \\
\hline 29 & 86 & 85 \\
\hline 30 & 87 & 89 \\
\hline 31 & 87 & 85 \\
\hline 32 & 88 & 95 \\
\hline 33 & 89 & 83 \\
\hline 34 & 89 & 91 \\
\hline 35 & 89 & 83 \\
\hline 36 & 90 & 79 \\
\hline 37 & 92 & 88 \\
\hline 38 & 92 & 84 \\
\hline 39 & 93 & 88 \\
\hline
\end{tabular}


Table A2 (continued)

Attitude Scores $\quad N=42$

\begin{tabular}{ccc}
\hline ID* & Pre-test & Post-test \\
\hline 40 & 95 & 85 \\
41 & 97 & 97 \\
42 & 98 & 79 \\
\hline
\end{tabular}

* ID numbers in Appendix D do not correspond to the ID numbers in Appendix E. 


\section{APPENDIX E}

\section{Figure 1}

Pre-test Knowledge Scores Frequency Distribution 
PRE-TEST KNOWLEDGE

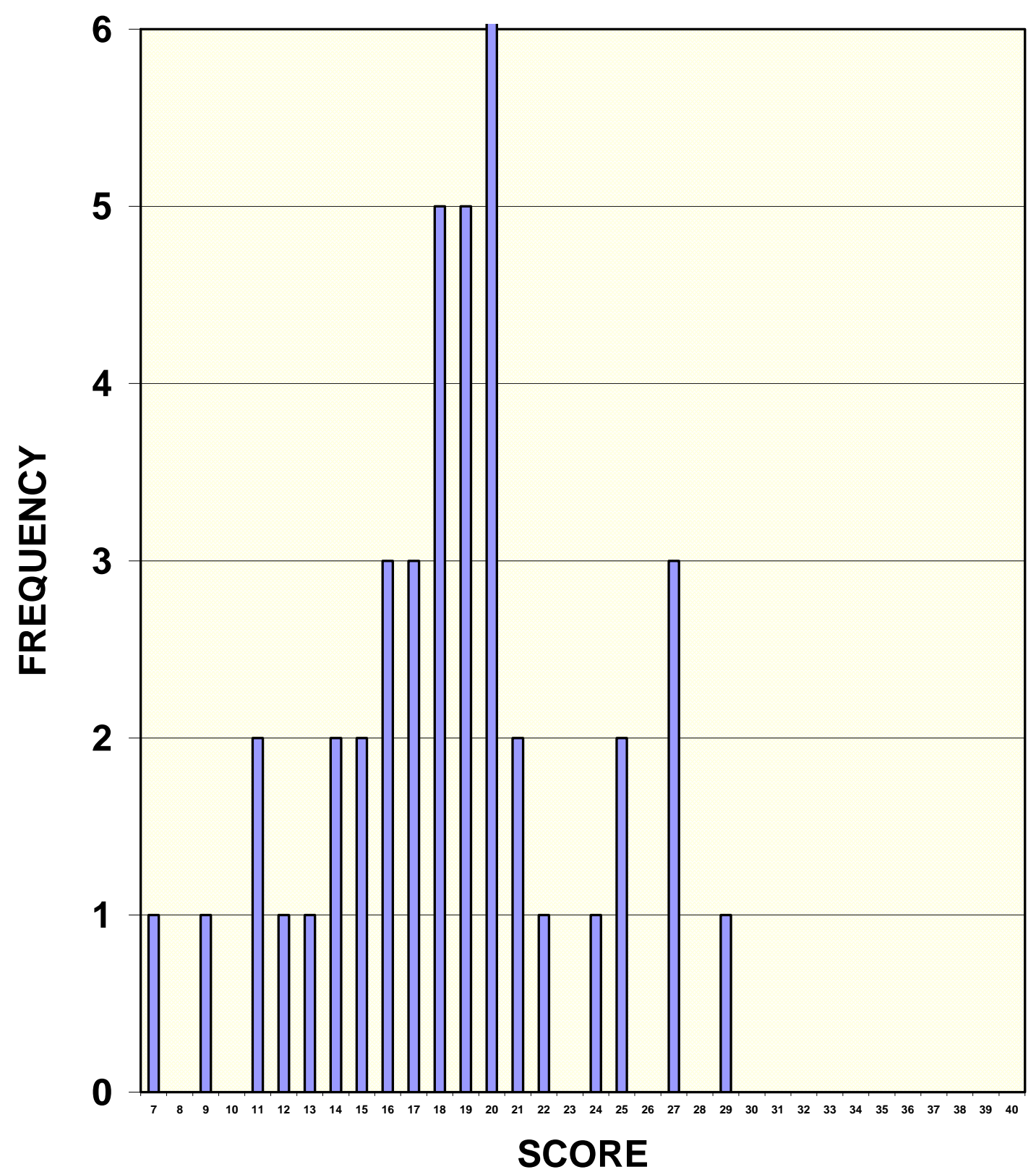

Figure 1

Pre-test Knowledge Scores Frequency Distribution 


\section{APPENDIX F}

Figure 2

Post-test Knowledge Scores Frequency Distribution 
POST-TEST KNOWLEDGE

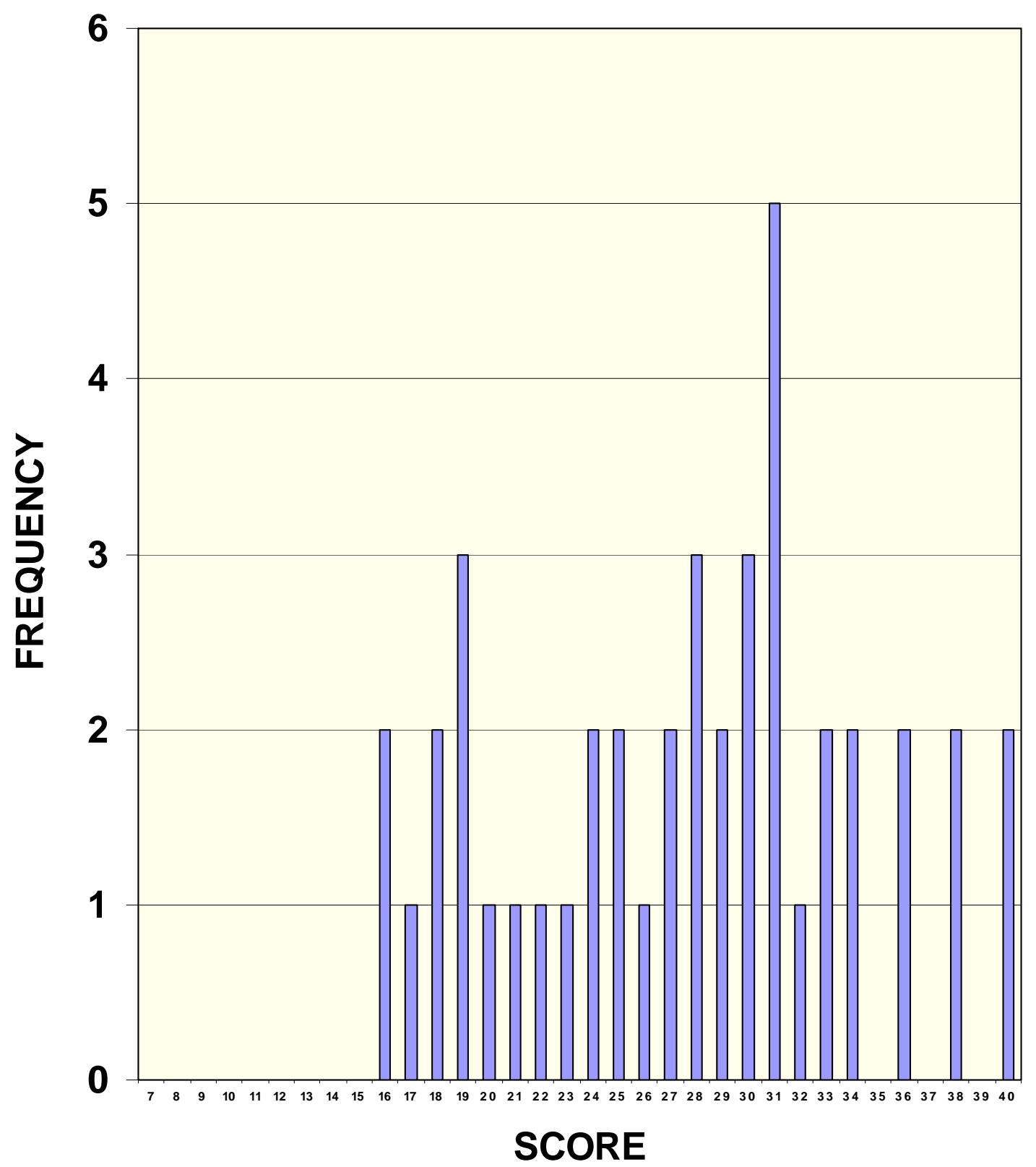

Figure 2

Post-test Knowledge Scores Frequency Distribution 


\section{APPENDIX G}

\section{Figure 3}

Pre-test Attitude Scores Frequency Distribution 


\section{PRE-TEST ATTITUDE}

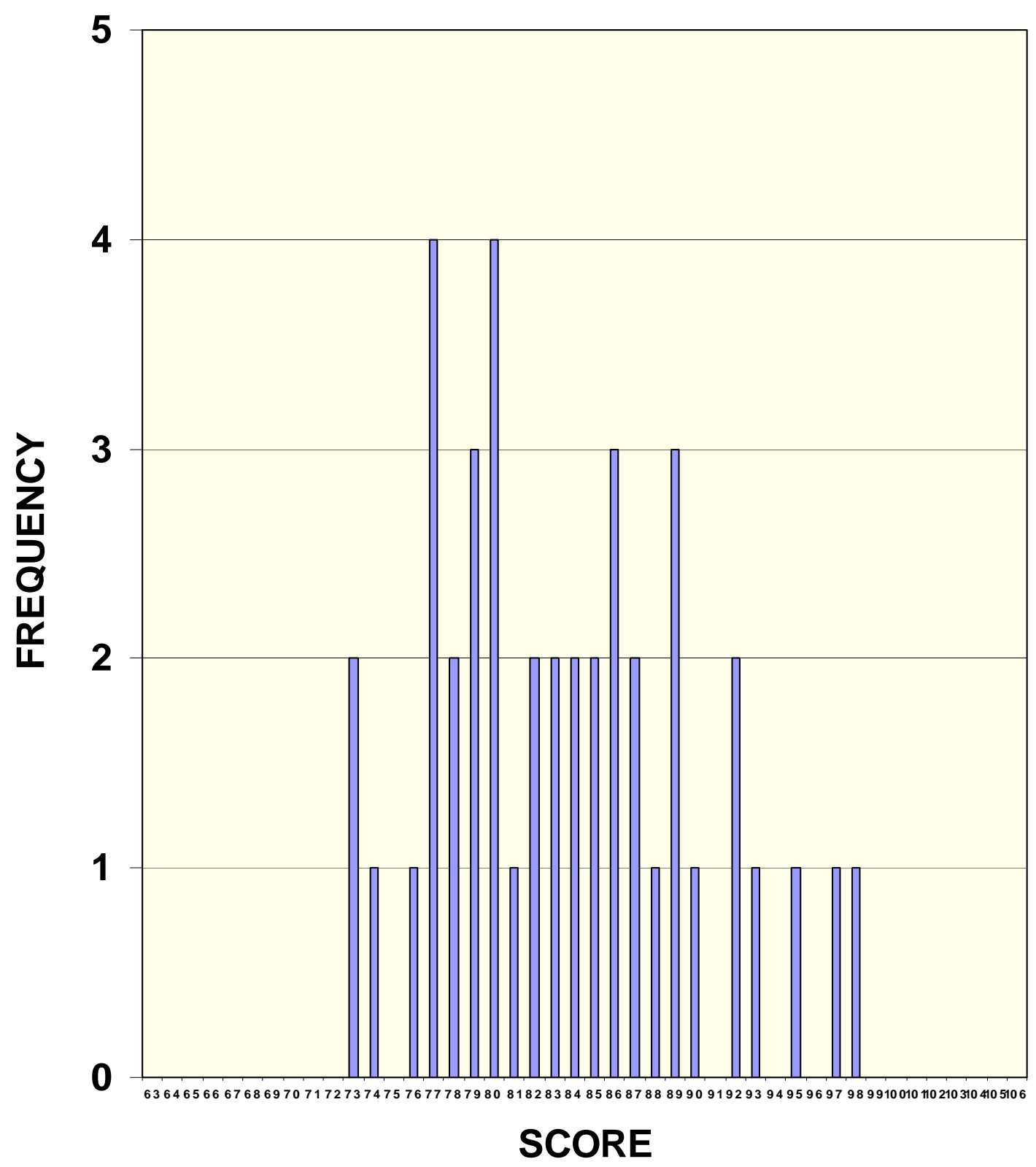

Figure 3:

Pre-test Attitude Scores Frequency Distribution 


\section{APPENDIX H}

\section{Figure 4}

Post-test Attitude Scores Frequency Distribution 
POST-TEST ATTITUDE

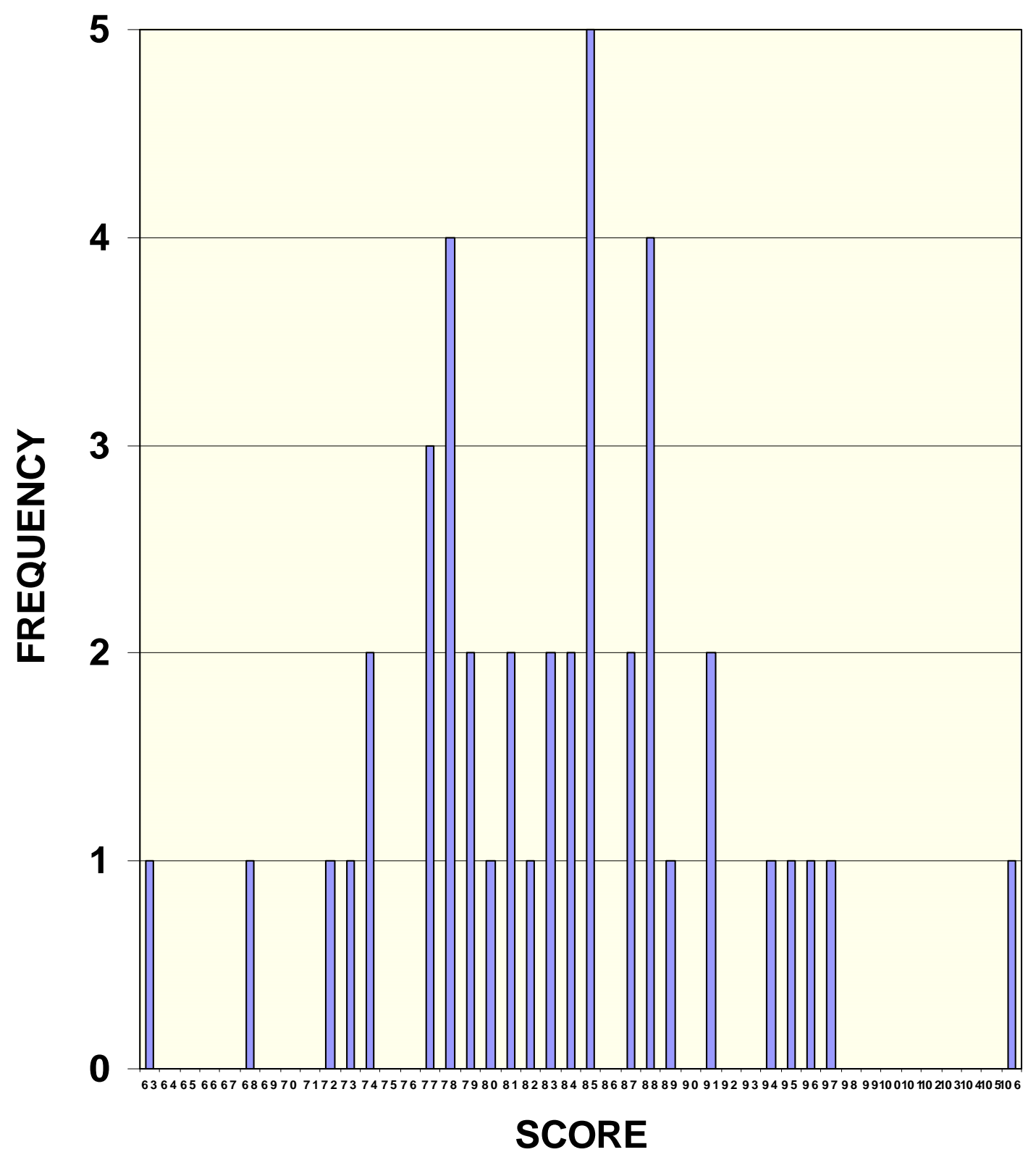

Figure 4:

Post-test Attitude Scores Frequency Distribution 
VITA

\section{Diane Krishon}

October 4, 1972

June, 1991

May, 1996

1996-1998

1999-2002

2002-present

August, 2004
Born: Sheboygan, Wisconsin

High School Graduation

Alan C. Pope High School

Marietta, Georgia

Bachelor of Science

Wildlife Biology

The University of Georgia

Athens, GA

Graduate Teaching Assistant

Division of Forestry

West Virginia University

Morgantown, WV

Science Teacher

Marlboro County High School

South Carolina

Science Teacher

Wando High School

South Carolina

Master of Science

Agricultural and Environmental Education West Virginia University

Morgantown, WV 